Revista de Estudios Histórico-Jurídicos

[Sección historia del derecho chileno]

XL (Valparaíso, Chile, 2018)

[pp. $341-370$ ]

\title{
HISTORIA DEL FALSO TESTIMONIO: ORÍGENES Y antecedentes de su Regulación en el Código Penal CHILENO DE 1874
}

[History of False Testimony: Origins and Background of its Regulation in the Chilean Penal Code of 1874]

\author{
Laura MAYER LUX* \\ Jaime Vera VeGA** \\ Pontificia Universidad Católica de Valparaíso, Chile
}

\begin{abstract}
RESUMEN
El presente trabajo analiza los orígenes y la evolución histórica del falso testimonio, hasta llegar a su consagración en el Código Penal chileno de 1874 . Con dicha finalidad, se estudia parte de su tratamiento en el Derecho Cuneiforme, así como su regulación en el Derecho Romano posterior a la dictación de las Leyes Silianas, el Derecho Visigodo, el Derecho Medieval y de la Edad Moderna, y de los primeros Códigos Penales franceses y españoles.
\end{abstract}

Palabras clave

Falsificación - Juramento - Perjurio Testigos - Perjuicio.

\section{Abstract}

This article analyzes the origins and historical evolution of false testimony, until reaching its regulation in the Chilean Criminal Code of 1874. With this purpose, it studies part of its treatment in Cuneiform Law, as well as its regulation in Roman Law after the enactment of Sulla Laws, Visigothic Law, Medieval Law and the Law of the Early Modern Period, and the Law of the first Penal Codes in France and Spain.

KeYwords

Falsification - Oath - Perjury Witnesses - Harm.

RECibido el 27 de abril de 2018 y ACEPTADO el 6 de julio de 2018

* Profesora de Derecho Penal en la Pontificia Universidad Católica de Valparaíso. Dirección postal: Brasil 2950, Valparaíso, Chile. Correo electrónico: laura.mayer@pucv.cl.

** Profesor de Derecho Penal y Derecho Procesal Penal en la Pontificia Universidad Católica de Valparaíso. Dirección postal: Brasil 2950, Valparaíso, Chile. Correo electrónico: jaime.vera@pucv.cl. 


\section{INTRODUCCIÓN}

La necesidad de dar fe sobre determinados hechos o de reconstruirlos a través de la declaración de testigos ha estado presente a lo largo de la historia, desde prácticamente los orígenes de la civilización ${ }^{1}$. A juicio de Carrara, el recurso al testimonio de terceros se vincula con la sospecha de que el que afirma algo en interés propio puede mentir fácilmente, dificultad que no se presentaría $-\mathrm{o}$ no con la misma intensidad-cuando es un tercero el que declara ${ }^{2}$.

El mismo Carrara destaca los medios elegidos por los pueblos más antiguos para garantizar la veracidad de lo declarado por los testigos: por una parte, se les imponía la obligación del juramento, con lo que el deber religioso se sumaba al cívico; por otra parte, se preveían graves castigos para quienes realizaban afirmaciones falsas sobre hechos social o jurídicamente relevantes ${ }^{3}$. A su vez, dichas sanciones podían entenderse como una consecuencia de la ofensa para la divinidad ${ }^{4} \mathrm{y}$-luego-para la administración de justicia, implicada en tales conductas.

En este desarrollo, la conducta punible consiste en emitir, verbalmente, una declaración falsa, siendo la falsedad recaída en documentos un delito bastante posterior 5 . De ahí que se sostenga que el falso testimonio constituye "el más antiguo de los delitos de falsedad" 6 .

El caso paradigmático de falso testimonio es aquel que se verifica en el contexto de un proceso judicial, en el que la declaración del testigo conforma una prueba fundante de la decisión del tribunal. A su respecto, ha sido tradicional la distinción entre los asuntos en los cuales se presta el testimonio (v. gr. penales o civiles), entre las disposiciones anímicas que tiene quien declara falsamente, así como entre que el testimonio sea a favor o en contra del interesado en la declaración. Ahora bien, la utilización de testigos en el tráfico jurídico no se limita sólo a los testimonios que se realizan en juicio, extendiéndose, en cambio, a otras situaciones en que su declaración puede ser de interés para el derecho.

Este trabajo tiene por objeto examinar los orígenes y la evolución histórica del falso testimonio, hasta llegar a su regulación en el Código Penal chileno de 1874. Para tales efectos, se estudiará parte de su tratamiento en el derecho cuneiforme, además de su estatuto en el derecho romano posterior a la dictación de las Leyes

${ }^{1}$ En esa línea, por ejemplo, AlejANDre, Juan Antonio, Falsedad testimonial, en ALEJANDre, Juan Antonio, Falsedad documental y falsedad testimonial. Estudio histórico-jurídico de dos tipos delictivos (Madrid, Dykinson, 2012), p. 79; IGLESIAS, Luis, El falso testimonio judicial en el derecho hispánico y anglo-sajón en el Medievo. Estudio comparado, en Revista en la España medieval, 40 (2017), p. 68.

2 Carrara, Francesco, Programa de derecho criminal. Parte Especial (trad. de José Ortega y Jorge Guerrero, Bogotá, Editorial Temis, 1961), V, p. 214.

${ }^{3}$ Carrara, Francesco, cit. (n. 2), V, p. 215.

${ }^{4}$ Véase Alejandre, Juan Antonio, cit. (n. 1), p. 79.

${ }^{5}$ En ese sentido Mayer Lux, Laura; Vera Vega, Jaime, Historia del objeto material del delito de falsedad documental punible, en Revista de Estudios Histórico-Jurídicos, 37 (2015), p. 328.

${ }^{6}$ Wilenmann, Javier, El concepto de falsedad en el falso testimonio. Una introducción a la dogmática general de los delitos de falsedad, en Revista Chilena de Derecho, 41/1 (2014), p. 59 n. 1 , con referencias ulteriores. 
Silianas, el derecho visigodo, el derecho medieval y de la Edad Moderna, y de los primeros códigos penales franceses y españoles.

Como veremos, con la evolución histórica que ha experimentado el falso testimonio se han ido configurando los principales elementos de dicho delito, entre los que pueden mencionarse la conducta que se realiza, el perjuicio que ella provoca, el contexto en el que se lleva a cabo, el fuero interno del autor y el juramento previo a la declaración.

Por otra parte, en el desarrollo histórico de la regulación relativa a las aserciones falsas de testigos se prevén sanciones caracterizadas, en términos generales, por su extrema dureza, que en muchos casos podían llegar incluso a la pena de muerte.

Finalmente, debe tenerse presente que, aunque es posible identificar etapas dentro del desarrollo del falso testimonio, ellas no suponen una separación tajante, sino que más bien una suerte de continuo histórico.

\section{Algunos AnteCedentes del falso testimonio en EL}

\section{DERECHO CUNEIFORME}

Probablemente el antecedente más remoto del falso testimonio como conducta punible se halla en las Leyes de Hammurabi, cuyo $\$ 3$ dispone: Si un señor aparece en un proceso para (presentar) un falso testimonio y no puede probar la palabra que ha dicho, si el proceso es un proceso capital tal señor será castigado con la muerte; mientras que el $\$ 4$ de las referidas leyes establece: Si se presenta para testimoniar (en falso, en un proceso) de grano o plata, sufrirá en su totalidad la pena de este proceso. Como puede advertirse, ya en una de las regulaciones más primitivas de la declaración falsa de testigos se establece un criterio de punición que -con más o menos matices- perdura hasta nuestros días, según el cual, el castigo de dicha conducta depende del asunto a propósito del cual se presta el testimonio mendaz. De ahí que se castigue con la muerte a quien realice un falso testimonio en un proceso en el que está en juego la vida del acusado; o que se sancione económicamente a quien lo lleve a cabo si lo que se discute es una reparación pecuniaria ${ }^{7}$.

Asimismo, el Pentateuco contiene algunas referencias a la declaración falsa de testigos, tanto en el Éxodo como en el Deuteronomio. En lo que respecta al Éxodo, la alusión al falso testimonio se expresa en uno de los diez mandamientos -el octavo-, en el que se dispone, genéricamente: No darás falso testimonio contra tu prójimo ${ }^{8}$. En el caso del Deuteronomio, el falso testimonio era sancionado de acuerdo con un sistema talional ${ }^{9}$, que podía llegar a la pena de muerte en supuestos

\footnotetext{
7 Véase Lara, Federico, Código de Hammurabi (Madrid, Tecnos, 1986), pp. 85 y s., nn. 108 y s.

8 Éxodo 20:16.

9 Deuteronomio 19:16-21: Cuando se levantare testigo falso contra alguno, para testificar contra él, entonces los dos litigantes se presentarán delante de Jehová, y delante de los sacerdotes y de los jueces que hubiere en aquellos días. Y los jueces inquirirán bien; y si aquel testigo resultare falso, y hubiere acusado falsamente a su hermano, entonces haréis a él como él pensó hacer a su hermano; y quitarás el mal de en medio de ti. Y los que quedaren oirán y temerán, y no volverán a hacer más una maldad semejante en medio de ti. Y no le compadecerás; vida por vida, ojo por ojo, diente por diente, mano por mano, pie por pie. Véase también VolochINSKY, Frida, Derecho penal en la
} 
de suma gravedad ${ }^{10}$. Como ocurre en otras expresiones del derecho cuneiforme, las leyes que regulaban la vida del pueblo judío tenían un claro carácter religioso, que también marcaba el sistema de delitos y penas previsto por ellas.

Por su parte, las Leyes de Manú reprimían el falso testimonio a través de numerosas reglas, y lo hacían imponiendo una sanción según su gravedad, como se desprende, por ejemplo, de la norma del capítulo 8. verso 98. Según éste, el falso testimonio debía castigarse con la muerte de parientes del testigo que emitía la declaración falsa, cuyo número dependía de si el testimonio concernía a pequeño ganado, a vacas, a caballos o a hombres, pudiendo extenderse a mil parientes en este último caso ${ }^{11}$. En estas leyes la confusión entre lo religioso y lo secular en la represión del falso testimonio es casi absoluta, como se deduce de la norma del capítulo 8. verso 82 , de acuerdo con el cual, los hombres deben dar evidencia verdadera y el que da falso testimonio cae en los lazos de Varuna ${ }^{12}$, sin poder oponer resistencia durante cien vidas ${ }^{13}$.

En la reconstrucción de la Ley de las XII Tablas, a partir de una referencia de Aulo Gelio a la Tabla VIII,23, se establecía el castigo penal del falso testimonio. Según ella, si alguno diere falso testimonio, será arrojado del monte Tarpeyo ${ }^{14}$. Lamentablemente dicha reconstrucción del texto transcrito deja dudas sobre una serie de elementos relevantes del comportamiento sancionado. Así, por ejemplo, no está claro si la declaración testimonial falsa debía realizarse judicialmente-o, más ampliamente, en algún negocio civil- o si asumía el carácter de una calumnia ${ }^{15}$. Por otra parte, también se contemplaba el castigo de la negativa a prestar testimonio cuando había sido públicamente asegurado a través del rito denominado obvagulatio $^{16}$. Para este último caso se establecía como pena la pérdida hacia el

antigüedad (Derecho penal hebreo, hindú y griego) (Memoria para optar al grado de licenciado en Ciencias Jurídicas y sociales, Santiago, Editorial Universitaria, 1961), p. 66.

${ }^{10}$ García, Ramiro; Larenas, Melissa, Los albores del derecho penal: la regulación del poder punitivo en los códigos sumerios, acadios y semitas, en Revista de Derecho Penal y Criminología, 37/102 (2016), p. 77.

${ }^{11}$ Véase BüHler, G., The Law of Manu, en Müller, F. Max (ed.), The Sacred Books of the East (Oxford, Clarendon Press, 1886), XXV, p. 271. En el capítulo 8. versos 120 y 121 también se contemplaban distintas penas, que dependían de la motivación que había tenido quien había emitido el falso testimonio. Véase cit. p. 275.

${ }_{12}$ Rodríguez, Francisco, El mito indio en la perspectiva del mito indoeuropeo, en Gerión: Revista de Historia Antigua (1989), p. 66, califica a "Varuna" como el dios protector del juramento y la justicia.

${ }_{13}$ Véase BÜHLER, G., cit. (n. 11), XXV, p. 269.

${ }^{14}$ Véase Digesto 20,1,53: si non illa etiam ex XII tab. de testimoniis falsis poena aboleuisset et si nunc quoque ut antea qui falsum testimonium dixisse conuictus esset, e saxo Tarpeio deiceretur. Véase asimismo Mommsen, Theodor, Römisches Strafrecht (Leipzig, Duncker \& Humblot, 1899), p. 668 n. 1 y MoncaYo, Socorro, El delito de falsedad en el derecho romano, en Revista Letras Jurídicas, 2 (2000), p. 1.

${ }^{15}$ Véase para la discusión Alejandre, Juan Antonio, cit. (n. 1), pp. 82 y s. con referencias ulteriores.

${ }^{16}$ Véase Cantarella, Eva, Los suplicios capitales en Grecia y Roma. Orígenes y funciones de la pena de muerte en la antigüedad clásica (Madrid, Ediciones Akal, 1996), p. 201. 
futuro de la capacidad de prestar testimonio, así como la correlativa incapacidad de llamar a otros para que testifiquen en favor propio $^{17}$.

\section{EL FALSO TESTIMONIO EN EL DERECHO ROMANO pOSTERIOR a La Dictación DE Las Leyes Silianas}

El tránsito entre el castigo de la declaración falsa de testigos contenido en la Ley de las XII Tablas y el contemplado en las Leyes Silianas no es un asunto claro. De acuerdo con Alejandre, es probable que el sistema punitivo decenviral "hubiera caído en desuso como consecuencia de la costumbre cada vez más extendida de consagrar los negocios jurídicos en escritura" ${ }^{18}$. Esta idea puede sustentarse en la regulación que tuvo el falso testimonio, por una parte, y la falsedad documental, por la otra. En efecto, mientras que este último delito aparece regulado de forma bastante sistemática en la Lex Cornelia de falsis, el falso testimonio resultaba castigado de forma casi anecdótica, junto con varios comportamientos, partiendo por el homicidio ${ }^{19}$, al que se agregaba el incendio y el robo, entre otros.

Concretamente, en la época post-decenviral, el falso testimonio fue regulado a través de la Lex Cornelia de sicariis et veneficis, que sancionaba con la deportación a quien, mediante falso testimonio, hiciere condenar en juicio a alguien por un crimen capital ${ }^{20}$. Tal comportamiento no aparecía castigado en la Lex Cornelia de falsis, no obstante ser ella la principal fuente que castigó el crimen falsis en la época que analizamos. Con todo, hay quienes aceptan una aplicación indirecta de la referida ley, bajo el entendido de que las declaraciones de los testigos se formalizaban en testationes $^{21}$, o sea, en documentos cuya falsedad sí quedaba abarcada por ella.

En la evolución histórica del falso testimonio marca un hito relevante la dictación del Senadoconsulto Liboniano del año 16 d.C. En Digesto 48,10,1 se contiene una referencia de Marciano a la aplicación de la pena de la Lex Cornelia de falsis al que con dolo malo hubiere procurado que se hicieren falsas declaraciones de testigos, o que se examinaren falsos testimonios ${ }^{22}$. Otra clara alusión al delito de falso testimonio se encuentra en Digesto 48,10,9,3, que a través de una

\footnotetext{
${ }^{17}$ SAnTAlucia, Bernardo, Diritto e processo penale nell'antica Roma (2a ed., Milano, Giuffrè, 1998), p. 57.

${ }^{18}$ Alejandre, Juan Antonio, cit. (n. 1), p. 83.

${ }^{19}$ Véase Cloud, J. D., The primary purpose of the lex Cornelia de sicariis, en Zeitschrift der Savigny-Stiftung für Rechtsgeschichte: Romanische Abteilung, 86/1 (1969), p. 258; LÉvITT, Albert, The Origin of the Doctrine of Mens Rea, en Illinois Law Review, 17 (1922-1923), p. 118.

${ }^{20}$ Véase Digesto 48,8,1: quive falsum testimonium dolo malo dixerit, quo quis publico indicio rei capitalis damnaretur; así como Sentencias de Paulo 5,21,1: [quive] falsum testimonium dixerit, quo quis periret, mortisve causam praestiterit. Véase igualmente D'ORs, Álvaro, Contribuciones a la historia del "crimen falsi», en Studi in onore di Edoardo Volterra (Milán, Giuffrè, 1969), II, p. 553. Sin embargo, como destaca BLÁNQUEZ, Carmen, Desigualdades sociales y praxis jurídica en Apuleyo, en Gerión: Revista de Historia Antigua (1987), p. 122, posteriormente los condenados de baja condición sufrirían la pena capital.

${ }^{21}$ D’Ors, Álvaro, cit. (n. 20), II, p. 554. Véase también Alejandre, Juan Antonio, cit. (n. 1), p. 85 .

${ }_{22}$ Digesto 48,10,1: Poena legis Corneliae irrogatur ei, qui falsas testationes faciendas, testimoniave falsa inspicienda dolo malo coniecerit.
} 
referencia de Ulpiano imponía la sanción de la Lex Cornelia de falsis, entre otros supuestos, a los que con dolo malo se hubieren unido para hacer falsos atestados o para prestar mutuamente falsos testimonios ${ }^{23}$. Asimismo, en Digesto 48,10,27, a través de una referencia de Modestino, se contemplaba el castigo para quienes prestaban testimonios diversos, como si hubieren cometido falsedad ${ }^{24}$; conducta a la que se agrega la indicada en Digesto $48,10,27,1$, consistente en prestar testimonio falso contra su propio signo ${ }^{25}$.

Posteriormente, se reguló la sanción de comportamientos vinculados con el falso testimonio tanto en el senadoconsulto Mesaliano del año 20 d.C. como en el senadoconsulto Geminiano del año 29 d.C. ${ }^{26}$. En virtud del primero, se castigaron conductas que suponían cobrar, pactar o asociarse para aportar abogados y testigos, así como asociarse para acusar a personas inocentes. La fuente principal de la que ello se desprende es la Collatio ${ }^{27}$, aunque debe reconocerse que existen dudas en torno a la exactitud del texto que las sancionaba ${ }^{28}$. De acuerdo con el senadoconsulto Geminiano se castigaban actos de corrupción ligados con la declaración de testigos ${ }^{29}$. En esa línea, se sancionaba con la pena de la Lex Cornelia de falsis a quien, por denunciar o no denunciar o dar testimonio, recibiere dinero ${ }^{30}$.

Del desarrollo que se desprende de las fuentes transcritas es posible formular algunas observaciones relativas al sentido y alcance del falso testimonio en el derecho romano posterior a la dictación de las Leyes Silianas. A diferencia de lo que ocurre en el derecho cuneiforme, en esta etapa ya pueden advertirse más claramente ciertas características del falso testimonio que están presentes a lo largo de la evolución de dicho ilícito.

A propósito de la conducta, el falso testimonio era una modalidad integrante del concepto genérico de crimen falsis. Esto implicaba que debía tratarse de un comportamiento falsario, cuyo rasgo principal era el hecho de concretarse en una declaración oral mendaz. Ahora bien, es probable que en esta etapa no existiera una delimitación clara entre el falso testimonio y la falsedad recaída en documen-

${ }^{23}$ Digesto 48,10,9,3: Poena legis Corneliae irrogatur ei, qui quid aliud, quam in testamento, sciens dolo malo falsum signaverit signarive curaverit; item qui falsas testationes faciendas testimoniave falsa invicem dicenda dolo malo coierint.

${ }^{24}$ Digesto 48,10,27: Eos, qui diversa inter se testimonia praebuerunt, quasi falsum fecerint, et praescriptio legis teneri pronuntiat.

25 Digesto 48,10,27,1: Et eum, qui contra signum suum falsum praebuit testimonium, poena falsi teneri pronuntiatum est [...].

26 Véase, por ejemplo, GREen, Stuart P., Deceit and the classification of crimes: federal rule of evidence 609 (A) (2) and the origins of crimen falsi, en The Journal of Criminal Law \& Criminology, $90 / 4$ (2000), pp. 1097 y s.

27 Collatio 8,7,2: Item qui ob instruendam aduocationem testimoniaue pecuniam acceperit pactusue fuerit societatemue coierit [...].

${ }^{28}$ Véase Torrent, Armando, El senadoconsulto Messaliano y el "Crimen Falsi", en Anuario de Historia del Derecho Español, 50 (1980), pp. 120 y ss.

29 Véase Moncayo, Socorro, cit. (n. 14), p. 4.

${ }^{30}$ Collatio 8,7,2: Sed et si quis ob denuntiandum uel non denuntiandum remittendumue testimonium pecuniam acceperit, senatus consulto quod duobus Geminis conss. factum est poena legis Corneliae adficitur. Et reliqua. 
tos, precisamente porque las declaraciones falsas de testigos podían consignarse en testationes.

Tratándose del elemento perjuicio, su presencia no se contemplaba expresamente en los delitos castigados, pero sí podía extraerse de algunas de sus exigencias. Ejemplo de lo señalado es la conducta prevista tras la dictación del senadoconsulto Mesaliano, que sancionaba a quien se asociare para acusar a personas inocentes. Pues bien, este comportamiento podría interpretarse en el sentido de que una persona -en este caso, alguien inocente- resultase perjudicada en términos relevantes por la declaración falsa del testigo. Al mismo tiempo, el hecho de que las fuentes contuvieran una alusión explícita a personas inocentes podría entenderse como una afectación a la idea de justicia y a su correcta administración.

En cuanto al contexto, llama la atención que no se exigiera declarar falsamente ante una autoridad con facultades jurisdiccionales. Tampoco es claro que se diferenciara entre el falso testimonio que, siendo delictivo, se realizaba a favor o en contra del acusado. La referencia al testimonio mendaz prestado en contra de una persona inocente nos lleva a pensar que el centro de atención estaba en este último supuesto. Sin embargo, la regulación del comportamiento está lejos de ser sistemática en esta materia.

Respecto del fuero interno, existen referencias bastante expresas a la disposición anímica del deponente. Tal es el caso de las diversas alusiones que se hacían al dolo malo con el que debe actuar el declarante. A ellas puede agregarse la exigencia, contenida en Digesto 48,10,9,3, en el sentido de que el deponente actuara, además, a sabiendas. Al parecer, los comportamientos cometidos con imprudencia eran más bien marginales y no tan relacionados con el falso testimonio en estricto sentido. Un ejemplo de ello lo encontramos en Digesto 48,10,27,1, que castigaba como responsable del delito de falsedad al que por imprudencia presentare dos testimonios diversos que resultasen contradictorios ${ }^{31}$.

En lo que atañe al juramento, no advertimos una exigencia clara de dicho rito en las fuentes analizadas. Alejandre ofrece una explicación respecto de este asunto. A su juicio, en el derecho romano clásico no parece haber sido exigible el juramento que, en cambio, sí habría adquirido gran importancia en la época cristiana $^{32}$. Con todo, en el Código Teodosiano se encuentran algunas referencias a dicho rito, que se establece con carácter obligatorio para los testigos ${ }^{33}$.

En relación con las penas aplicables, es posible advertir una relativa morigeración de los castigos a imponer a quien cometiere falso testimonio respecto de la etapa anterior. Si bien no es claro el momento a partir del cual se produce una atenuación del régimen punitivo, es probable que a ella haya contribuido la Lex

${ }^{31}$ Digesto 48,10,27,1: [...] De impudentia eius, qui diversa duobus testimonia praebuit, cuius ita anceps fides vacillat, quod crimine falsi teneatur, nec dubitandum est.

32 Alejandre, Juan Antonio, cit. (n. 1), p. 88.

${ }^{33}$ Código Teodosiano 11,14,2: Iurisiurandi religione testes prius, quam perhibeant testimonium, iam dudum arctari praecepimus, et ut honestioribus potius fides testibus habeatur. Simili more sanximus, ut unius testimonium nemo iudicum in quacunque causa facile patiatur admitti. Et nunc manifeste sancimus, ut unius omnino testis responsio non audiatur, etiamsi praeclarae curiae honore praefulgeat. 
Cornelia de falsis. En virtud de dicha normativa, tratándose de comportamientos llevados a cabo por honestiores, la pena no era la capital, sino que la deportación ${ }^{34}$. Este castigo ya había sido considerado en el acotado supuesto de falso testimonio de la Lex Cornelia de sicariis et veneficis. De esta forma, comenzó a aplicarse una sanción que, pese a su gravedad, era considerablemente menos severa que la pena de muerte.

\section{El falso testimonio en el Derecho Visigodo}

El análisis separado de la regulación del falso testimonio prevista en el derecho visigodo halla su justificación en las importantes transformaciones que experimentó la misma en esta etapa histórica ${ }^{35}$. Por una parte, la Lex Romana Visigothorum recogió la normativa referida en las Sentencias de $\mathrm{Paulo}^{36}$, así como la consagrada en el Código Teodosiano ${ }^{37}$. Por otra parte, la regulación contenida en el Liber, producto de las reformas introducidas a dicha fuente por Chindasvinto, supuso cambios tanto para la conducta como para la pena del falso testimonio.

En lo que se refiere al comportamiento, su sanción se vio ampliada a través del castigo del inductor y del inducido ${ }^{38}$, a lo que se añade un listado de sujetos inhábiles para prestar testimonio ${ }^{39}$. Otro aspecto destacable es que se contemplaron sanciones para quien declaraba falsamente y también para quien negaba conocer

${ }^{34}$ No obstante, la pena prevista para los humiliores sí era la capital. Véase Sentencias de Paulo 5,23,1: honestiores quidem in insulam deportantur, humiliores autem aut in metallum dantur aut in crucem tolluntur: serui autem post admissum manumissi capite puniuntur; así como IGLESIAS, Luis, El falso testimonio judicial, cit. (n. 1), p. 71.

35 En esto se diferenció la regulación de las falsedades documentales de aquella que tuvo el falso testimonio, ya que respecto de las primeras el Derecho Visigodo no implicó el cambio que supuso para el segundo. En relación con las falsedades documentales véase MAYER LUX, Laura; Vera Vega, Jaime, cit. (n. 5), p. 334.

${ }^{36}$ Lex Romana Visigothorum 5,25,2: Qui ob falsum testimonium perhibendum vel verum non perhibendum pecuniam acceperit, dederit, iudicemve, ut sententiam ferat vel non ferat, corruperit corrumpendumve curaverit, humiliores capite puniuntur; honestiores publicatis bonis cum ipso iudice in insulam deportantur.

37 Véase Alejandre, Juan Antonio, cit. (n. 1), p. 95.

38 Liber Iudiciorum 2,4,9: Si quis contra hominem ingenuum et adversus libertum aliquem provocasse convincitur falsum dicere testimonium, tantum illi conponat, quem per falsam testificationem conabatur addicere vel damnare, quantum, si iuste eum obtinuisse, poterat de istatu vel de rebus eius adquirere. Si vero testis, simpliciter ab alio ad testimonium invitatus, false contra ingenuum adque libertum testificare dinoscitur, qualiter per eius testimonium in servitute quisque humiliaretur, et tamen ille, qui testem protulit, conscius fraudis huius non invenitur, solus testis ipse superiori sententia, id est, sicut ille, qui testem ad falsum testimonium provocabit, ei, quem suo testimonio decipere voluerit, obnoxius maneat; ita ut, si non habuerit unde conponat, in potestate eius cum id, quod habere videtur, perenniter serviturus tradatur. Id autem et de illis decernimus observandum, qui, ut servos alienos ad libertatem perducerent, aut falsum testimonium dixisse repperiuntur aut eam intentionem adibere conati sunt, ut ab eis provocati per eorum instantiam ad ingenuitatis libertatem indebita possent aliquatenus insultatione venire.

39 Liber Iudiciorum 2,4,1: Homicide, malefici, fures, criminosi sive venefici, et qui raptum fecerint vel falsum testimonium dixerint, seu qui ad sortilegos divinosque concurrerint, nullatenus erunt ad testimonium admittendi. 
la verdad, como se indica en Liber $2,4,2^{40}$. De acuerdo con Iglesias, ya que con Ervigio comenzó a castigarse toda declaración falsa, sin distinción, resultaba punible el falso testimonio emitido en contra de una de las partes, pero también la "verdad silenciada" o el testimonio mendaz efectuado en favor de una de ellas ${ }^{41}$.

De otro lado, en Liber 2,4,6 se tiene en cuenta el perjuicio causado como criterio para determinar la pena pecuniaria por aplicar ${ }^{42}$. Mientras que, en cuanto al contexto en el que debía prestarse la declaración, existen múltiples referencias al falso testimonio otorgado ante una autoridad judicial en el marco de un proceso, v. gr. en Liber 2,4,2; 2,4,6 y 2,4,8.

También en Liber 2,4,6 se contiene un reforzamiento del elemento subjetivo de quien prestaba el falso testimonio, sujeto que debía obrar con una voluntad específica al llevarlo a cabo ${ }^{43}$. Por su parte, según Liber 2,4,2, el rito del juramento constituyó una exigencia explícita de la declaración de quien actuaba como testigo.

En lo que respecta a la pena, en Liber 2,4,2 se sancionaba al maior que cometía falso testimonio con la inhabilitación perpetua para declarar como testigo; y al minor libre se le castigaba con esa misma inhabilidad, así como con cien azotes y difamación. A su turno, en Liber 2,4,6 se sancionaba al maior que cometía falso testimonio con la confiscación de bienes correspondiente al daño irrogado e inhabilitación perpetua para declarar como testigo. En cambio, al minor que lo cometía se le castigaba con la degradación al carácter de esclavo de la víctima del falso testimonio. Finalmente, en Liber 2,4,9 se sancionaba al inductor con una pena pecuniaria y degradación al carácter de esclavo de la víctima del testimonio mendaz, que podía llegar a ser perpetua si el responsable no enmendaba la falsedad.

De la evolución experimentada por el falso testimonio durante esta etapa es posible plantear algunas observaciones en relación con su sentido y alcance. En términos generales, puede afirmarse que con el derecho visigodo comenzaron a consolidarse los elementos que definen la moderna fisionomía de dicho ilícito.

${ }^{40}$ Liber Iudiciorum 2,4,2: Iudex, causa finita et sacramentum secundum leges, sicut ipse ordinaverit, a testibus dato, iudicium emittat; quia testes sine sacramento testimonium peribere non possunt. Quod si ab utraque parte testimonia equaliter proferantur, discussa prius veritate verborum, quibus magis debeat credi, iudicis extimabit electio. Certe si admonitus quisquam a iudice de re, quam novit, testimonium peribere noluerit, aut si nescire se dixerit, id ipsum etiam iurare distulerit et per gratiam aut per venalitatem vera subpresserit: si nobilis fuerit, testimonium postea in nullo iudicio dicere permittatur, nec testimonium ipsius recipiatur ulterius. Quod si, licet ingenue, minoris tamen fuerint dignitatis persone, et testimonium careant et c flagella infamati suscipiant; quia non minor reatus est vera subprimere quam falsa confingere.

${ }^{41}$ IgLESIAS, Luis, El falso testimonio judicial, cit. (n. 1), p. 73.

${ }^{42}$ Liber Iudiciorum 2,4,6: Si quis contra alium falsum testimonium dixerit et in mendacio invenitur, aut certe si ipse dixerit, quia falsum testimonium dedit: si maioris loci persona est, det illi de propria facultate sua, contra quem falsum testimonium dixerat, tantum, quantum per testimonium eius perdere debuit, et se testificare ultra non noverit. Quod si minoris loci persona est et non habuerit unde conponat, ipse tradatur in potestate illi, contra quem falsum testimonium dixerat, serviturus. Quicumque autem vel beneficio corruperit aliquem vel circumventione qualibet falsum testimonium dicere persuaserit, dum evidens huius rei conmentum patuerit, tam autor sceleris, qui in interitum intendit alterius, quam his, qui rerum aviditate cupidus testificande prebuit falsitatis adsensum, pari simul sententia falsarii teneantur.

43 Ídem. Véase igualmente Alejandre, Juan Antonio, cit. (n. 1), p. 99. 
A propósito de la conducta, si bien operaron las ampliaciones relativas al castigo del inductor y del inducido, mencionadas supra, el comportamiento central que se sancionaba era la declaración mendaz prestada en calidad de testigo. Respecto de las primeras, lo que sí resulta destacable es que se castigase de forma clara la instigación al falso testimonio que, en época romana, parecía más bien asociarse con actos de corrupción relativos a ese comportamiento, en especial, con recibir dinero por llevarlo a cabo ${ }^{44}$.

Tratándose del perjuicio, éste era apreciado para efectos de determinar la pena aplicable, como ocurría cuando se imponía el castigo de confiscación de bienes, que debía equivaler al daño irrogado con la declaración falsa. Sin embargo, el hecho que se castigase todo falso testimonio, independientemente de si éste resultaba perjudicial o favorable para una de las partes, hacía que el daño causado perdiera parte de su significación.

En cuanto al contexto, tras analizar las fuentes del derecho visigodo, en especial el Liber, queda de manifiesto que el ámbito en el que paradigmáticamente debía prestarse el testimonio mendaz era ante una autoridad judicial y en el marco de un proceso. Esto plantea una diferencia importante con la etapa anterior -el derecho romano posterior a las Leyes Silianas-, en la que, como vimos, no se exigía declarar falsamente ante una autoridad con facultades jurisdiccionales.

Respecto del fuero interno, resulta llamativo que no se contemplaren referencias explícitas al dolo en la regulación del Liber relativa al falso testimonio, no obstante ellas sí existían en la normativa que dicha fuente preveía para las falsedades documentales ${ }^{45}$. Esto también resulta destacable si se tiene en cuenta que en la regulación de ese ilícito contemplada en el Digesto, ya analizada, hay referencias expresas al dolo malo ${ }^{46}$. Por otra parte, la pena del inductor introdujo matices a lo que había sido hasta ahora la disposición anímica del agente. En ese sentido, como indica Alejandre, se castigaba "la declaración dolosamente inexacta hecha por un testigo ante el juez, tanto si ha sido libre y espontánea como si ha sido inducida por otra persona" ${ }^{47}$.

En lo que atañe al juramento, su consolidación como una exigencia para entender configurado el delito de falso testimonio puede entenderse como una consecuencia del vínculo que el propio Liber estableció entre dicho ilícito y la divinidad. Así, en Liber 2,4,8 se contienen alusiones expresas al hecho de que el falso testimonio no sólo suponía una infracción a las leyes de los hombres, sino que también una vulneración a las leyes de Dios. En ese orden de ideas, es probable que el auge del cristianismo en esta época haya implicado una suerte de retorno a la valoración del falso testimonio que imperó en el derecho cuneiforme.

Finalmente, el derecho visigodo supuso una evidente atenuación de las penas a imponer al falso testimonio, si se lo compara con las existentes en el derecho romano. En efecto, como tuvimos ocasión de examinar, a pesar de que el derecho romano posterior a la dictación de las Leyes Silianas ya había apuntado

\footnotetext{
44 Véase Collatio 8,7,2.

45 Véase, por ejemplo, Liber Iudiciorum 7,5,7.

46 Véase especialmente Digesto 48,10,9,3.

47 Alejandre, Juan Antonio, cit. (n. 1), p. 98.
} 
a una morigeración del castigo aplicable, con una imposición muy acotada de la pena de muerte, en el derecho visigodo ésta fue claramente superada. En su lugar, adquirieron protagonismo sanciones como la confiscación de bienes y la inhabilitación para declarar como testigo, a las que se añadió la degradación al carácter de esclavo de la víctima del falso testimonio en determinados supuestos.

\section{El FALSO TESTIMONIO EN EL DERECHO ALTOMEDIEVAL:}

LA SUPERVIVENCIA DEL LIBER Y LAS PARTICULARIDADES DEL

\section{DERECHO CATALÁN}

En lo que respecta a la regulación del falso testimonio durante la Alta Edad Media, debe tenerse presente que ésta fue una época extensa desde el punto de vista temporal, en la que existieron fuentes fragmentarias de la normativa aplicable, además de periodos en los que no hubo total certeza sobre cuál era dicha normativa.

Si nos centramos en el análisis de las fuentes que son relevantes para nuestro estudio, esto es, los antecedentes históricos del falso testimonio regulado en el Código Penal chileno de 1874, deberemos considerar el estatuto de dicho comportamiento en la Península Ibérica, concretamente en España.

Existe cierto consenso en orden a que el Liber siguió rigiendo en dicha zona geográfica ${ }^{48}$, sin embargo, como plantea Iglesias, su recurso "no ha de entenderse como una aplicación directa de la ley escrita, sino como referente jurídico que se trasmite de generación en generación de forma oral y que adquiere carácter de derecho general supletorio u orientador [... "49 . Lo anterior supuso, en términos generales, una continuidad en el desarrollo histórico del falso testimonio desde el derecho romano y visigodo ${ }^{50}$.

Dicha situación general de pervivencia del Liber en España encontró un importante matiz en la regulación existente en Cataluña ${ }^{51}$, particularmente a través del estatuto del falso testimonio contenido en los denominados Usatges y, luego, con las reformas introducidas por Alfonso I y Jaime I.

En lo que concierne a la regulación establecida en los Usatges, existe controversia en torno a si el Usatge número 85 efectivamente se refirió al falso testimonio, ya que su texto alude expresamente al perjurio ${ }^{52}$. Esta discusión probablemente encuentra su origen en que dicha norma, a pesar de referirse al perjurio, contenía elementos que son propios del falso testimonio, como el rito del j u r a m e $\mathrm{n}$ t o, unido a la circunstancia de dar te s t i m o $\mathrm{n}$ i $\mathrm{o}^{53}$.

${ }^{48}$ Véase, por ejemplo, IgLESIA, Aquilino, El derecho en la Cataluña Altomedieval, en Memorias de la Real Academia de Buenas Letras de Barcelona, 24 (1991), p. 29.

${ }^{49}$ IGLESIAS, Luis, El falso testimonio judicial, cit. (n. 1), p. 77, n. 70.

${ }^{50}$ Véase, con referencia a la monarquía astur-leonesa, ORLANDIS, José, Huellas visigóticas en el derecho de la Alta Edad Media, en Anuario de Historia del Derecho Español, 15 (1944), p. 644.

${ }^{51}$ Sobre las razones históricas que dieron origen a un derecho catalán distinto del de otros territorios peninsulares véase PINO, Miguel, La pena de confiscación de bienes en el derecho histórico español (Córdoba, Diputación Provincial de Córdoba, 1999), p. 354.

52 Véase Alejandre, Juan Antonio, cit. (n. 1), pp. 114 y ss.

53 Usatge 85: Precipimus ut perjuria caveantur, nec admittantur testes ad juramentum antequam discuciantur; et si aliter discuti non possunt, separentur ad invicem et singulariter inquirantur. Et 
Alfonso I, por su parte, introdujo una reforma plasmada en el Usatge número 143, que vino a castigar supuestos específicos de falsedad testimonial. En primer lugar, se sancionó al litigante que inducía a otro a prestar falso testimonio ante el rey o sus representantes. En este caso la pena aplicable era la pérdida del pleito y la confiscación de bienes. En segundo lugar, se castigó al declarante que cometía falso testimonio. En este supuesto la pena aplicable, además de la confiscación de bienes, era la pérdida de la mano y de la lengua ${ }^{54}$.

Jaime I también modificó esta materia, al regular los Usatges 161, 162 y 165. El primero de ellos se refería a una hipótesis de perjurio que, de acuerdo con lo señalado, no aparecía tan claramente delimitado del falso testimonio. Teniendo en cuenta lo anterior, el Usatge número 161 poseía dos características llamativas. Por una parte, el agente debía actuar por interés económico o personal; por otra parte, la pena prevista era la confiscación de la cuarta parte de los bienes del autor del delito, cantidad que se imponía en favor de la persona en contra de la cual se hubiese cometido el perjurio ${ }^{55}$.

El segundo de dichos Usatges, o sea, el número 162, contemplaba expresamente un supuesto de falso testimonio. La particularidad en este caso radicaba en que no se exigía un propósito particular, pudiendo ejecutarse el delito por cualquier motivo. Además, en este supuesto la pena también podía ser la confiscación, que se calculaba en consideración al perjuicio irrogado a aquel en contra de quien se hubiese llevado a cabo el comportamiento ${ }^{56}$.

En lo que atañe al Usatge número 165, éste preveía un caso de falso testimonio omisivo, que castigaba a quien no quisiere decir aquello que sabía, ni declararlo como testigo, o dijere que no lo sabía, o no lo quisiere jurar, o callase la verdad

non liceat accusatori testes eligere absente accusato suo. Et omnino nullus nisi jejunus ad sacramentum vel testimonium admittatur. Et ille qui ad testimonium adducitur, si refutatur, dicat ipse qui eum refutat vel probet quare eum recipere noluerit. Et de ipso pago, non de altero, testes eligantur, nisi forte longius extra comitatum causa sit inquirenda. Et si quis convictus fuerit perjurii, manum perdat aut centum solidos redimat. Éste puede consultarse en Valls, Fernando, Los Usatges de Barcelona (Barcelona, Promociones Publicaciones Universitarias, 1984), p. 97.

54 Usatge 143: Quoniam ex conquestione subjectorum frequenter querelam suscepimus quod propter testium corrupcionem veritas offuscatur et deprimitur, imperiales leges in hac parte sequentes, sanccimus quod, si quilibet testis ab aliquo productus fuerit, in sacramento comprehendat, nec sibi, nec se sciente, alicui subjecte persone peccuniam vel aliam rem fuisse datam vel promissam. Preterea, falsitatem testium per quos veritati contraria proferuntur omnino compescentes, jubemus, sub examine nostri vel cujuslibet a nobis delegati, littigantem qui scienter falsum testem produxerit vel corrumperit, amissionem cause sustinere et omnium bonorum mobilium dumtaxat publicacionem incurrere: quorum bonorum medietas domino ipsius assignentur, et medietas erario nostro servetur. Sed eandem penam sustineat circa publicacionem bonorum qui falsum tulisse testimonium convictus fuerit, et insuper manum amittat et linguam, possessionibus utriusque devolvendis hiis qui jure successorio ad eorum bona vocantur. Éste puede consultarse en VAlLs, Fernando, cit. (n. 53), p. 115.

55 Usatge 161: Si quis per amorem peccunie aut per amorem amici vel propinqui sui perjuraverit, quartam partem de omnibus rebus suis, ei cui falsitatem juraverit, componat, et testimonium amittat. Éste puede consultarse en VALLS, Fernando, cit. (n. 53), p. 121.

56 Usatge 162: Si quis falsum testimonium contra proximum suum aliquo casu dixerit vel fecerit, tantum de suo avere perdat quantum proximus suus amisisset si veritatem, contra eum testificando, dixisset. Éste puede consultarse en VALLS, Fernando, cit. (n. 53), p. 121. En realidad, la norma es bastante amplia y sugiere que el castigo aplicable podía exceder de la mera confiscación de bienes. 
por favor o venalidad. En este supuesto la pena aplicable era la inhabilidad para prestar testimonio en el futuro. Asimismo, dicho Usatge consagraba una especie de eximente de responsabilidad penal, ya que excluía el castigo si el testigo callaba la verdad por temor a la muerte o a la mutilación de su cuerpo ${ }^{57}$.

A partir del estudio efectuado de los Usatge 161, 162 y 165, es posible realizar algunos comentarios sobre al sentido y alcance del falso testimonio en el derecho altomedieval, y particularmente sobre su estatuto en el derecho catalán.

En primer lugar, según se señaló, se advierte en esta etapa una ausencia de delimitación entre las figuras que hoy se conocen como perjurio y falso testimonio $^{58}$. Lo expresado se evidencia en el hecho de que los Usatges 85 y 161 aludían explícitamente al perjurio, mientras que los Usatges 162 y 165 se referían a la declaración falsa de testigos.

Una cuestión que no es clara es qué normativa resultaba aplicable si en Cataluña se llevaba a cabo un supuesto de falso testimonio. Tratándose de la regulación previa a las modificaciones realizadas por Alfonso I y Jaime I, las alternativas eran fundamentalmente dos: una, que se aplicara el Liber in totum al falso testimonio, rigiendo el Usatge número 85 sólo para el perjurio; otra, que se impusiera este último también al falso testimonio, rigiendo el Liber-eventualmente- para los casos no cubiertos en ese Usatge. Por su parte, la regulación posterior a las reformas de Alfonso I y Jaime I es muestra de que el Liber iba perdiendo vigencia en relación con los Usatge de Cataluña, toda vez que éstos contenían disposiciones que expresamente aludían al falso testimonio y que, por tanto, debían tener aplicación.

A propósito de la conducta, el vínculo entre el perjurio y el falso testimonio introdujo matices a lo que había sido la regulación de este último en la tradición romana. En efecto, si se considera el estatuto del falso testimonio previsto en el derecho romano, dicho comportamiento integraba el crimen falsis, bajo el cual se englobaban conductas relacionadas con soportes falsificados, pero también relativas a declaraciones mendaces. La falta de una delimitación clara entre el perjurio y el falso testimonio, en cambio, permitía calificar a dicho comportamiento como una falsedad personal, en la que no se atendía al soporte falseado, sino que a la emisión oral de una afirmación falsa. A ello debe agregarse que, como en el sistema visigodo, se preveía una pena para el litigante que inducía a otro a prestar falso testimonio.

Tratándose del elemento perjuicio, también existen referencias explícitas al mismo en los Usatges 161 y 162 . Así, tratándose del primero, si bien la pena no dependía del perjuicio irrogado, el monto confiscado (cuarta parte de los bienes del autor del delito) se imponía en favor de la víctima, operando con ello como una forma de reparación pecuniaria. En el caso del Usatge número 162, la alu-

57 Usatge 165: Opportet itaque cunctos homines vera que sciunt testificari et judici convenit illos ad hoc vocare; sed si admonitus aliquis a judice dicere id quod novit et testimonium prohibere noluerit, aut eciam se nescire dixerit ad ipsum jurare noluerit, et per graciam vel per venalitatem verum superrexerit, nisi metu mortis vel corporis sui debilitacione hoc taceat, testimonium ipsius non recipiatur ulterius, quia non minor reatus est vera subprimere quam falsa confringere. Éste puede consultarse en VALLS, Fernando, cit. (n. 53), pp. 121 y s.

${ }^{58}$ En esa línea IgLESIAS, Luis, El falso testimonio judicial, cit. (n. 1), p. 84. 
sión al perjuicio es más directa, ya que la sanción aplicable a quien cometía falso testimonio se hacía depender de la pérdida sufrida por su víctima.

En cuanto al contexto, la confusión entre perjurio y falso testimonio llevó a creer que el delito debía ejecutarse a propósito de declaraciones prestadas ante autoridades. Desde este punto de vista, no se divisan elementos para afirmar que el comportamiento debía necesariamente realizarse ante un juez. Sin embargo, el Usatge número 143 especificó el contexto de comisión de la conducta delictiva, que en el caso del litigante que inducía a otro a prestar falso testimonio debía llevarse a cabo ante el rey o sus representantes.

Respecto del fuero interno, existieron referencias más o menos explícitas a la disposición anímica del autor. Así, en el caso del comportamiento regulado en el Usatge número 161, se exigió expresamente actuar por interés económico o personal. En cambio, tratándose del Usatge número 165, la alusión al fuero interno fue menos evidente, toda vez que castigó callar la verdad por favor o venalidad. Frente a ellos, en los supuestos previstos en los Usatges 85, 143 y 162 era posible llevar a cabo el falso testimonio por cualquier motivo.

En lo que atañe al juramento, si se parte de la base de que en esta etapa existió una confusión entre el perjurio y el falso testimonio, es posible sostener que el rito del juramento sí se encontraba implicado en los comportamientos. En ese sentido, no debe perderse de vista que el perjurio supone realizar una declaración falsa bajo juramento, cuestión que resultaba claramente exigible respecto de los delitos regulados en los Usatges 85 y 161 .

En relación con las penas aplicables, a pesar de que existió una imposición bastante generalizada de la pena de confiscación, resultaba muy llamativa la severidad con que se sancionaban algunos supuestos de falso testimonio, más aún si se tiene en cuenta que en Cataluña muchos delitos eran castigados con la obligación de enmendar o componer ${ }^{59}$. En ese sentido, además de existir penas de corte talional ${ }^{60-61}$, se preveían castigos que incluso involucraban afectaciones permanentes para la integridad física del hechor, como ocurre con la pérdida de la mano y de la lengua contemplada en el Usatge número 143.

59 Véase López-Amo y Marín, Ángel, El derecho penal español de la Baja Edad Media, en Anuario de Historia del Derecho Español, 26 (1956), p. 553; TERraDAs, Ignasi, Justicia vindicatoria: de la ofensa e indefensión a la imprecación y el oráculo, la vindicta y el talión, la ordalía y el juramento, la composición y la reconciliación (s. 1., Consejo Superior de Investigaciones Científicas, 2008), p. 274.

${ }^{60}$ Resulta interesante la pena contemplada en el Usatge número 162, cuyo tenor literal establecía la pérdida, para el autor del falso testimonio, de cuánto su prójimo hubiese perdido por dicho delito. Pues bien, si se atiende a lo que efectivamente pudo haber perdido el afectado con la declaración mendaz, la pena podría haber abarcado tanto sanciones pecuniarias como de otra índole, e incluso la muerte del hechor, si es que su falso testimonio hubiere acarreado esa consecuencia para el ofendido.

${ }^{61}$ Dicho régimen también se contemplaba en fuentes canónicas del Altomedievo relativas al falso testimonio que, estableciendo la pena de excomunión, disponían que ésta se impusiera por el juez eclesiástico considerando la clase de delito que el testigo mendaz le hubiese imputado a otro. Véase IgLESIAS, Luis, El falso testimonio judicial, cit. (n. 1), p. 74. 


\section{EL FALSO TESTIMONIO EN EL DERECHO BAJOMEDIEVAL Y DE la EdAd Moderna}

En lo que concierne a la regulación del falso testimonio durante la Baja Edad Media, debe tenerse en cuenta que ésta fue una época extensa desde una perspectiva temporal, en la que nuevamente existieron fuentes fragmentarias de la normativa aplicable. Ahora bien, si nos centramos en la regulación de dicho delito en España, por su relevancia para el Código Penal chileno de 1874, es posible distinguir entre el periodo bajomedieval temprano y la etapa bajomedieval tardía.

En el periodo bajomedieval temprano, el Liber siguió rigiendo en España, en términos análogos a lo acaecido durante la Alta Edad Media. En ese sentido, "los ordenamientos locales del bajomedievo temprano se limitan a reproducir las disposiciones del Liber Iudiciorum readaptando el régimen sancionador a su costumbre local" ${ }^{2}$, lo que supuso una continuidad en el desarrollo histórico del falso testimonio desde el derecho romano y visigodo. Pero, junto con el Liber, rigieron estatutos particulares de ese delito en ciertas zonas geográficas, cuyas especificidades, principalmente en lo que respecta a las penas, amerita un examen separado.

Uno de tales estatutos se contenía en el Fuero de León, que además de aludir expresamente al falso testimonio -y no al perjurio, como en parte aconteció en la etapa anterior-, disponía una pena doble: primero, la destrucción de la casa del declarante ${ }^{63}$, desde los cimientos; segundo, el hecho que su testimonio no fuese admitido en adelante por nadie ${ }^{64}$. Similares penas preveían los Fueros de Villafranca del Bierzo ${ }^{65}$, de Laguna de $\operatorname{Negrillos}^{66}$ y de Puebla de Sanabria ${ }^{67}$.

${ }^{62}$ IgLESIAS, Luis, El falso testimonio judicial, cit. (n. 1), p. 83.

${ }^{63}$ En cuanto a esta pena, destaca su origen germánico GuZMán, José Luis, La pena y la extinción de la responsabilidad penal (Santiago, LegalPublishing, 2008), p. 241 con referencias ulteriores.

${ }^{64}$ Fuero de León, Art. XIX: Si autem aliquis testium falsum testificasse probatus fuerit, reddat pro falsitate Règi LX solidos, et illi ex quo falsum protulit testimonium, quidquid suo testimonio perdidit reddat integrum; domusque illius falsi testis destruantur á fundamentis, et deinceps á nullis recipiatur in testimoniis.

${ }^{65}$ Fuero de Villafranca del Bierzo, 18: Se algun for prouado por falsa testimoña, peyte sessenta sueldos [...]; y el desque o falso testimonio dier que quier que outro por lo sou testimonno perder entreguello todo y a sua casa sera testruida, y dali en adelante en testimonio nunca sera reçebido. Éste puede consultarse en RodríGUEZ, Justiniano, Los Fueros del Reino de León (León, Ediciones Leonesas, 1981), II: Documentos, p. 153.

${ }^{66}$ Fuero de Laguna de Negrillos, 18: Si alguno fuese provado por falso testimonio, peche sesenta sueldos [...], ca qualquier que dixere falso testimonio de entregamiente al otro quanto perdiese por ser testigo, e derribenle la casa, e dende en adelante non sea resçebido en testimonio. Éste puede consultarse en RodrígueZ, Justiniano, cit. (n. 65), II: Documentos, p. 177.

${ }^{67}$ Fuero de Puebla de Sanabria, 18: Si provado fuere contra alguno que dixo falso testimonio, peche sessenta sueldos. E tenemos por bien que estos sueldos se departan en tres partes: la primera sea dada al rey, la segunda al conceio, la tercera a los alcaldes; e torne a aquél, contra quien dio el testimonio falso, enteramientre todo lo que perdió por su testimonio. E lo que dize en el otro privilegio, que la su casa sea derribada por esta razón, ésto non tenemos nos por guisado, ca esto tornarle en danno de nos e de la nuestra puebla. Mas tenemos por bien e por derecho quel tagen la lengua con que dixo el falso testimonio, despreciando mandamento de Dios e mintiendo al alcalde, delante quien da el testimonio, e queriendo empeceer a su vezino o a otro qualquier por falso testimonio. El texto 
En el caso de la pena del falso testimonio contemplada en el Fuero de León, la severidad del castigo debe analizarse desde una perspectiva histórica y no según las sanciones que, para ese delito, existen en la actualidad. En ese sentido, resulta acertada la opinión de Muñoz y Romero, quien ve un adelanto en la destrucción de la casa del testigo mendaz, si se la compara con su reducción a la categoría de esclavo, establecida en el Liber y, luego, en el Fuero Juzgo ${ }^{68}$.

Otra regulación especial del falso testimonio se consagraba en el Fuero de Zorita de los Canes, que sancionaba a quien firmaba o juraba una declaración falsa. La pena aplicable a dicho supuesto era triple, y abarcaba una sanción pecuniaria correspondiente al doble del valor de lo discutido en juicio; la inhabilitación perpetua para otorgar un testimonio; y la publicidad edictal del delito ${ }^{69}$. Además, tratándose de casos en que el falso testimonio era cometido por el juez o alcalde, se preveía una pena adicional, consistente en la pérdida de dicho oficio ${ }^{70}$.

Especialmente simbólica era la sanción establecida en los Fueros de Borja y Zaragoza que, a juicio de Zambrana, habrían buscado "dejar una huella física permanente" 71 en quien efectuaba la declaración falsa. En concreto, tal normativa contemplaba la pena consistente en trasquilarlo en cruz con el badajo de una campana caliente y marcarlo a fuego con una cruz en la frente ${ }^{72}$.

indicado se encuentra transcrito, aunque sin la numeración señalada, en ANTA-LoRENZO, Lauro, El fuero de Sanabria, en Studia Historica. Historia Medieval, 5 (1987), p. 169. Un comentario sobre las diferencias en el tratamiento otorgado al falso testimonio en los Fueros de Villafranca del Bierzo, Laguna de Negrillos y Puebla de Sanabria puede consultarse en Rodríguez, Justiniano, Los Fueros del Reino de León (León, Ediciones Leonesas, 1981), I: Estudio crítico, p. 177.

${ }^{68}$ Muñoz y Romero, Tomás, Colección de fueros municipales y cartas pueblas de los reinos de Castilla, León, Corona de Aragón y Navarra (Madrid, Ediciones Atlas, 1978), p. 150.

${ }^{69}$ Fuero de Zorita de los Canes, 813: Otroquesi mando, que tod aquel que falso testimonio firmare o iurare, peche la peticion doblada, sicon testigos fuere uençido, et sobre todo esto, en testimonio dalli adelante nunca sea reçebido, et el su nonbre que sea encartado, quela mala fama de su falsedad mas sea publicada et mas acreçentada, o iure por pleito de su cofradia ode su collaçion. Aquel otroquesi que aotro acusare de falsa iura ode falsa firma, et gelo non pudiere prouar, peche LX menkales alos alcaldes et al querelloso. En el doble del falso testimonio ayan los alcaldes otroquesi parte. Éste puede consultarse en De Ureña y Smenjaud, Rafael, El Fuero de Zorita de los Canes según el Códice 217 de la Biblioteca Nacional (Siglo XIII al XIV). Sus relaciones con el Fuero Latino de Cuenca y el Romanceado de Alcázar (Madrid, Establecimiento Tipográfico de Fortanet, 1911), p. 358. Véase también IgLeSIAS, Luis, El falso testimonio judicial, cit. (n. 1), p. 86.

${ }^{70}$ Fuero de Zorita de los Canes, 335: Et si por auentura, el iuez o el alcalde, de mentira ode falsedat depues dela iura uencido fuere, pierda el oficio, o el portiello de conceio, et sobre todo aquesto sea encartado que dende adelante non sea recebido en testimonio. E todo danno quanto por aquella ocasion uiniere, pechelo doblado. Et aquesta misma pena aya el iuez o el alcalde que la uerdat escondiere, o otra cosa enterogare alas firmas si no lo queles iudgare, o mentira firmare, o non fuere fiel alconceio, omenospreciare el iudizio del fuero, o defendiere al escriuano que no lea el fuero amenazandolo, o por palauras asperas denostandolo. Éste puede consultarse en DE UREŃA Y SMenjaud, Rafael, cit. (n. 69), pp. 178 y s.

${ }^{71}$ Zambrana, Patricia, Rasgos generales de la evolución histórica de la tipología de las penas corporales, en Revista de Estudios Histórico-Jurídicos, 27 (2005), n. 85.

${ }^{72}$ Fueros de Borja y Zaragoza, 87: De testibus falsis. Si probati sunt falsi testes, et iam probati sunt cum aliis testibus, transquirentur in cruces, et cum batallo campane calenti crement illos in fronte in cruces, et expellantur a villa pro falsis et malis; quia sicut vox campane auditur per diversa loca, ita iniuria et infamia eorum nota sit ubique gentibus. Éstos pueden consultarse en MORALES, 
A lo anterior se añadía la regulación del falso testimonio contenida en el Fuero de Soria, que castigaba a toda persona que, con conocimiento, firmare falsamente una cosa o aumentare su testimonio más allá de lo que supiere. En dichas hipótesis al autor del delito se le imponía pagar la demanda doblada a aquel en contra de quien había declarado, se le quitaban los dientes y se le inhabilitaba para ser testigo en el futuro ${ }^{73}$.

Con independencia de las regulaciones particulares que acabamos de indicar, en el periodo Bajomedieval tardío se advierte una continuidad en el estatuto del falso testimonio de la tradición romanavisigoda, a través de su recepción en la traducción al romance del Liber Iudiciorum, conocida como Fuero Juzgo. Según ello, en esta etapa la conducta supuso una declaración falsa del testigo, que actuaba con la voluntad específica de llevarla a $\mathrm{cabo}^{74}$. Además, se exigía que él prestara juramento, sancionándose su comportamiento principalmente cuando era ejecutado ante una autoridad judicial, en el marco de un proceso. Fuera de ese caso se preveía el castigo para el inductor y la pena, si era pecuniaria, se determinaba según el perjuicio causado ${ }^{75}$.

En términos generales, el Fuero Real no se alejó de la regulación romanavisigoda del falso testimonio, siendo dos las normas relevantes en esta materia. El Libro 2, 8, 13, imponía al testigo mendaz pagar cuanto hizo perder a aquel contra quien declaró falsamente. Y si no tenía con qué pagar, el hechor podía ser puesto en poder de aquél hasta que pagara. Dicha norma también castigaba al que corrompía a otro para que cometiera falso testimonio, debiendo imponerse tanto al primero como el segundo la pena de los falsos ${ }^{76}$. Esa sanción se encontraba regulada en el Libro 4, 12, 3, que castigaba a quien diese falso testimonio después de que jurare o callase la verdad que supiera. En este caso, en términos análogos al Fuero de Soria, al hechor se le imponía pagar la demanda a aquel que

Juan José; Pedraza, Manuel José, Fueros de Borja y Zaragoza. Edición crítica e indices (Zaragoza, Anubar Ediciones, 1986), p. 44.

${ }^{73}$ Fuero de Soria, 279: Toda firma que firmare falsa mjentre aquella cofa en que non fue njn fe açerto o acreçiere en $f_{u}$ teftimonjo mas de quanto non fopiere, fi lo connofçiere él fuere firmado, peche la demanda doblada a aquel contra quien ujniere firmar, quinten le los dientes nunca maf uala fu teftimonjo. Efta mifma pena aya aquel que demandare a otro en juyzio que firmo falfedat contra el o contra otri, fi gelo non pudiere firmar o moftrar con razon derecha.

${ }^{74}$ Con todo, GÓmEZ, Juan, Algunos tipos de delitos recogidos en nuestra legislación histórica desde el Fuero Juzgo hasta las Recopilaciones, en Anales de la Universidad de Murcia (1947), p. 522, matiza esta idea, al afirmar que el sujeto podía ser sancionado si faltaba a la verdad por resentimiento, en cuyo caso se le prohibía ser testigo en el futuro.

${ }^{75}$ Véase el punto $\mathrm{V}$.

${ }^{76}$ Fuero Real 2, 8, 13: Si algun ome dixiere falso testimonio contra otro, e despues fuere fallado en la falsedat, o él mismo manifestare que la dixo, peche a aquel contra quien dixo la falsedat cuantol fizo perder por ella: et si non ovier de que lo pechar, sea metido en poder de aquel contra quien dijo la falsedat, e sirvase dél fasta que gelo peche: et el pleito en que él testimonió, por decir el falso testimonio non debe seer desfecho, fuera si pudiese seer provado por buenas testimonias o por buen escripto. Et todo ome que corrompiere a otro por ruego, o por algo quel dé, o quel prometa, o por algun engaño, $e$ le fecier decir falso testimonio, el que lo corrompió, e el que dijo la falsedat, ayan la pena de los falsos. 
la perdió por su falso testimonio, se le inhabilitaba para testificar en el futuro y se le quitaban los dientes ${ }^{77}$.

En las Siete Partidas se destinaba un acápite especial para el castigo del falso testimonio que, en líneas gruesas, repetía varios de los elementos característicos de la tradición romana-visigoda que se venía asentando respecto de dicho delito. Tal regulación se hallaba en la Partida 7,7, 1, que incluía una serie de conductas agrupadas bajo una misma noción de falsedad, a la que se definía como "mudamiento de la verdad"78. En lo que atañe a las conductas, se castigaba al testigo que era llamado a un pleito y decía falso testimonio o negaba la verdad sabiéndola ${ }^{79}$. Además, se incluían dos modalidades de inducción al falso testimonio consistentes en dar o recibir precio para declarar en un pleito y corromper maliciosamente al testigo sobre el contenido de su declaración o para que encubriera la verdad o la negara ${ }^{80}$.

Particularmente destacable resulta la regulación del juramento contemplada en la Partida 3,16, 24, pues aludía detalladamente a la ritualidad que debía seguirse al momento de jurar. Ella implicaba colocar las manos sobre los Santos Evangelios, además de jurar decir la verdad por Dios, por los Santos y por aquellas palabras que son escritas en los Evangelios. Este estatuto ponía de relieve el sentido religioso que tenía el juramento como elemento necesario para la configuración del delito de falso testimonio ${ }^{81}$. No obstante, de la Pradilla, hacia el siglo XVI, plantea una idea que relativiza la importancia que habría tenido el juramento en las Partidas, pues afirma que quien comete falso testimonio recibirá la pena de los falsos aun cuando no hubiese prestado juramento ${ }^{82}$.

77 Fuero Real 4, 12, 3: Todo ome, que dixiere falso testimonio, pues que jurare o callare la verdat que sopiere, e quel fuere demandada, e él despues dixiere que negó la verdat o que dixo falsedat, el fuer provado, peche la demanda a aquel que la perdió por él, e nunqua mas vala su testimonio, $e$ quintenle los dientes: et esta misma pena aya aquel, que aduxiere los testimonios para decir falsedat, e lo ellos dixieren.

78 Partidas 7, 7, 1: Falsedad es mudamiento de la verdad.

79 Partidas 7, 7, 1: E avn la faze el que es llamado por testigo en algun pleyto, si dixiere falso testimonio, o negare la verdad, sabiendola.

${ }^{80}$ Partidas 7, 7, 1: Esso mismo faze el que da precio a otro, por que non diga su testimonio en algun pleyto, de lo que sabe. Otrosi lo faze, el que lo recibe, e non quiere dezir su testimonio porende; ca tambien el que lo da, como el que lo recibe, ambos fazen falsedad. Otrosi dezimos, que qualquier ome, que muestra maliciosamente a los testigos en que manera digan el testimonio, con intencion de los corromper, porque encubran la verdad, o que la nieguen, que faze falsedad.

${ }^{81}$ Partidas 3, 16, 24: La manera de como deue jurar el testigo delante el Judgador, es esta: deue poner las manos sobre los Santos Euangelios, e jurar, que diga verdad de lo que sopiere en razon del pleyto sobre que es aducho, tambien por la vna parte como por la otra; e que en diziendola non mezclara y falsedad; e que por amor, ni por desamor, ni por miedo, nin por cosa que le sea dada, o prometida, nin por daño, nin por pro que el atienda ende auer, non dexara de dezir la verdad, ni la encubrira; e que toda cosa que sopiere de aquel pleyto sobre que es aducho por testigo, que la dira, maguer non gela pregunte el Judgador. E aun deue jurar, que non descubrira a ninguna de las partes lo que dixo, dando su testimonio, fasta que el Juez lo aya publicado. E todas estas cosas deue jurar por Dios, e por los Santos, e por aquellas palabras que son escritas en los Euangelios. Pero si el testigo fuesse Arzobispo, o Obispo, non ha por que poner las manos sobre los Euangelios. Mas abonda que jure, que dira verdad segun que le conuiene, estando los Euangelios delante, assi como de suso diximos.

${ }^{82}$ De la Pradilla, Francisco, Suma de las leyes (Madrid, Imprenta Real, 1644), p. 13. 
En cuanto al régimen de penas, éste se encontraba definido de manera específica para el falso testimonio en la Partida 3, 11, 26, sin perjuicio de la aplicación de la pena general prevista para los falsos en la Partida 7, 7,6 (que al parecer podía imponerse de forma facultativa ${ }^{83}$ ). La pena concreta se establecía según un sistema talional, pudiendo consistir en pagar el equivalente al perjuicio provocado por el falso testimonio o incluso matar o dejar lisiado al hechor si el afectado hubiese recibido el mismo castigo ${ }^{84}$. A lo anterior se agregaba la inhabilitación para ser testigo contemplada en la Partida 3, 16, $8^{85}$. Por su parte, la pena general para los falsarios se hacía depender de la calidad de hombre libre o siervo. En el caso de los hombres libres, la sanción consistía en el destierro a una isla y la pérdida de los bienes -que debían ser entregados a los herederos o a la Cámara del Rey-; en el supuesto de los siervos, en cambio, la pena era la capital ${ }^{86}$.

Finalmente, en la etapa bajomedieval se puede destacar la regulación del delito de falso testimonio contenida en la ley número 83 de las Leyes de Toro. Este estatuto se caracterizó igualmente por castigar dicho comportamiento a partir de un sistema talional ${ }^{87}$, que podía significar incluso la pena de muerte ${ }^{88}$. Además, las

${ }^{83}$ Esta posibilidad se vincula con las penas arbitrarias, previstas en las Leyes de Estilo, $\mathrm{CXV}$, en relación con las sanciones que podía imponer el alcalde; que además es documentada por Castillo de Bobadilla, Jerónimo, Politica para corregidores, y señores de vassallos, en tiempo de paz, y de guerra (Valladolid, Imprenta Real, 1649), II, p. 669, respecto de los castigos que podía aplicar el juez.

${ }^{84}$ Partidas 3, 11, 26: Mentira jurando alguno en pleyto, dandole su contendor la jura, o el Judgador, non le podemos poner otra pena, si non aquella que Dios le quisiere poner. Ca pues que su contendor le dio la jura, o el Judgador, diziendole que serian pagados, por lo que el jurasse, non le puede poner otra pena: mas si alguno fuesse aducho por testigo, e despues que ouiere jurado, le pudieren prouar, que juro mentira a sabiendas, debe pechar a aquel contra quien firmo, todo quanto perdio por su testimonio; e demas pueden darle pena de falso. E si por su testimonio mentiroso fue alguno muerto, o lisiado que reciba el mismo otra tal pena.

${ }^{85}$ Partidas 3, 16, 8: Otrosi non puede ser testigo ome contra quien fuesse prouado, que dixera falso testimonio.

${ }^{86}$ Partidas 7, 7, 6: Vencido seyendo alguno por juyzio, o conosciendo sin premia, que auia fecho alguna de las falsedades que diximos en las leyes ante desta; si fuere orme libre, deue ser desterrado para siempre en alguna isla; e si parientes ouiere, de aquellos que suben, o descienden por la liña derecha, fasta el tercer grado, deuen heredar lo suyo. Mas si tales herederos non ouiesse, estonce los bienes suyos deuen ser de la Camara del Rey, sacando ende las debdas quedeuia, e la dote, e las arras de su mugen e si fuere siervo, deue morir por ello.

87 Véase Pacheco, Joaquín Francisco; González y Serrano, José, Comentario histórico, crítico y jurídico á las Leyes de Toro (Madrid, Imprenta y Fundición de M. Tello, 1876), II, p. 472.

${ }^{88}$ Leyes de Toro, 83: Quando se provare, que algun testigo depuso falsamente contra alguna persona, o personas en alguna causa criminal, en la qual sy no se averiguase su dicho ser falso, aquel o aquellos contra quien depuso merescia pena de muerte, o otra pena corporal, que al tal testigo, averiguandose como fue falso, le sea dada la misma pena en su persona, e bienes, como se le deviera dar a aquel o a aquellos contra quien depuso, seyendo su dicho verdadero, caso que en aquellos contra quien depuso no se execute la tal pena, pues por él no quedó de dar gela; lo qual mandamos que se guarde e execute en todos los delitos de qualquier calidad que sean, e en las otras causas criminales e civiles, mandamos que contra los testigos que depusieren falsamente se guarden e executen las leyes de nuestros reynos que sobrello disponen. 
Leyes de Toro establecían de manera explícita la distinción entre falso testimonio prestado en causa civil y falso testimonio otorgado en causa criminal ${ }^{89}$.

Dicho régimen penológico sufrió modificaciones oscilantes en la Edad Moderna, primero, a través de conmutaciones de los castigos previstos y, luego, mediante un retorno a las penas contempladas para los falsarios "sin ninguna dispensacion ni moderacion" $"$.

En cuanto a las conmutaciones, puede señalarse la pragmática de Carlos I, de 31 de enero de 1530, 16 de mayo de 1534 y 23 de febrero de 1535, que previó una sustitución de las penas corporales por la de galeras ${ }^{91}$; la pragmática de D. Carlos y D. ${ }^{a}$ Juana en Monzón de 25 de noviembre de 1552, que contempló, asimismo, la conmutación de las penas ordinarias de los delitos por el servicio de galeras ${ }^{92}$; y la pragmática de Felipe II, de 3 de mayo de 1566, que previó específicamente la sustitución de la pena consistente en quitar los dientes a los testigos falsos por la de vergüenza pública y servicio de galeras ${ }^{93}$.

En lo que respecta al retorno que experimentó la penalidad del falso testimonio a los castigos establecidos en el derecho bajomedieval, puede indicarse el auto acordado de D. Felipe V en Madrid, y el Consejo a 26 y 28 de julio de 1705, titulado "Rigorosa observancia de las leyes y sus penas contra los delatores y testigos falsos" ". No obstante, según opinión de Bernì, en la práctica dicho rigor fue morigerado a través de la aplicación de multas, apercibimientos, destierros o presidios, que habrían sido impuestos según la gravedad de las causas y la calidad de las personas ${ }^{95}$.

A propósito de la conducta, es posible destacar algunos rasgos interesantes de la regulación del falso testimonio del derecho bajomedieval y de la Edad Moderna. En primer lugar, pese a que en estos periodos se advierte una continuación del estatuto romano-visigodo referente a dicho delito, el falso testimonio comenzó a perfilarse como una figura delictiva independiente del perjurio, con determinados elementos característicos. Con todo, la exigencia del juramento como requisito previo a la declaración -establecido explícitamente en varias de las fuentes consultadas- sigue planteando una muy estrecha vinculación entre ambos comportamientos. Esta última circunstancia se mantuvo incluso durante los tiempos modernos, pues, como se ha señalado, la exigencia del juramento como requisito para la punibilidad de la conducta era una cuestión que los comentaristas de esa época hacían depender de la legislación respectiva, lo que también podría constituir un indicio de que en ese entonces no existía una distinción muy clara entre los delitos de falso testimonio y perjurio ${ }^{96}$. En segundo lugar, en esta etapa

\footnotetext{
${ }^{89}$ Ibidem.

90 Novísima Recopilación 12, 6, 6.

${ }^{91}$ Novísima Recopilación 12, 40, 1.

92 Novísima Recopilación 12, 402.

93 Novísima Recopilación 12, 6, 5. Véase también IgLESIAs, Luis, Estudio comparado de las penas corporales en el derecho hispánico e inglés en la Edad Moderna, en Anuario de Historia del Derecho Español, 86 (2016), p. 321.

${ }^{4}$ Novísima Recopilación 12, 6, 6.

95 Bernì, Joseph, Practica criminal (Valencia, Simon Faure, 1749), p. 18.

${ }^{96}$ Rodríguez, Christian, Tratamiento del falso testimonio en las Leyes de Toro, en Revista de
} 
se consolidó la idea de que el comportamiento sancionado incluía, además de la declaración falsa, la omisión de la verdad. En tercer lugar, existió en general una regulación del castigo tanto para quien efectuaba el falso testimonio como para quien instigaba a otro a que lo llevara a cabo. En cuarto lugar, algunos criminalistas medievales y modernos, entre los que se puede mencionar a Julio Claro, Farinacio y los prácticos franceses del Siglo XVIII, comenzaron a exigir, como requisito para la punición de la conducta, que la alteración de la verdad recayese sobre algún extremo esencial de la declaración del testigo ${ }^{97}$.

Tratándose del elemento perjuicio, su reconocimiento en la regulación del falso testimonio puede hallarse en la consagración de ciertos castigos, que tenían en cuenta el daño producido por el delito. Así ocurre, por ejemplo, en el Fuero Juzgo, cuyo criterio para consagrar la pena pecuniaria era, derechamente, el perjuicio irrogado. Algo similar ocurre en las Partidas, pues sus penas incluían, entre otras cosas, pagar el equivalente al perjuicio causado.

En cuanto al contexto, el Fuero Juzgo sancionaba el falso testimonio principalmente cuando era realizado ante una autoridad judicial, lo cual importaba una delimitación del ámbito en el cual podía llevarse a cabo el comportamiento. Mucho más precisa era la regulación que efectuaban las Leyes de Toro, que diferenciaban expresamente entre el falso testimonio otorgado en una causa civil y aquel que era prestado en una causa penal.

Respecto del fuero interno, hay en las fuentes algunas referencias al mismo, como ocurre en el Fuero de Soria, que reprimía a quien "con conocimiento" firmaba falsamente una cosa o aumentaba su testimonio; o bien, en el Fuero Juzgo, que partía de la base de que el testigo mendaz actuaba "con la voluntad" específica de llevar a cabo la conducta incriminada. También resulta destacable el supuesto de inducción al falso testimonio previsto en las Siete Partidas, que castigaba al que corrompiere "maliciosamente" al testigo.

En lo que atañe al juramento, su reconocimiento como exigencia previa a la declaración generaba, según lo señalado supra, que existiera una relación directa entre el falso testimonio y el perjurio. Fuera de ello, hay en algunas fuentes referencias explícitas a dicho requisito, v. gr. en el Fuero de Zorita de los Canes, que sancionaba a quien firmaba o juraba una declaración falsa; o en el Fuero Real, que castigaba, entre otras cosas, a quien daba falso testimonio después de haber jurado. A lo dicho se suma la pormenorizada regulación que de ese rito se contempló en las Partidas que, según lo ya indicado, destacaba el sentido religioso del mismo.

En relación con las penas aplicables, éstas son muy variadas en cuanto a su severidad. Así, según las fuentes que lo regulan, el falso testimonio se castigaba con la inhabilidad para ser testigo, sanción que podía considerarse entre las más leves. A ella se agregaba la destrucción de la casa del testigo mendaz, así como penas que incidían en su integridad física, v. gr. marcarlo a fuego con una cruz en la frente o quitarle los dientes. En fin, también se preveía la pena de muerte que, según las Partidas, era aplicable a los siervos que cometían falso testimonio.

Derecho Universidad Católica del Norte (1999), p. 194.

${ }^{97}$ En este sentido Culllo Calón, Eugenio, Derecho penal. Revisado y puesto al día por Cesar Camargo Hernández (14 ${ }^{\mathrm{a}}$ ed., Barcelona, Bosch, 1980), p. 325, n. 4. 
De acuerdo con lo señalado supra, en la Edad Moderna hubo una tendencia a morigerar la severidad de los castigos previstos en las fuentes, fundamentalmente mediante una sustitución de la pena de muerte y los castigos corporales por la pena de galeras. Sin embargo, esta atenuación del rigor de las sanciones, como destaca Tomás y Valiente, no pareció tener su origen en un propósito humanizador, sino que más bien se justificó en razones utilitarias de carácter político-militar, atendida la mayor necesidad en esa época de hombres para el remo ${ }^{98}$.

\section{El FALSO TESTIMONIO EN LOS PRIMEROS CÓDIGOS PENALES FRANCESES Y ESPAÑOLES}

Por su influencia en el proceso codificador chileno, fueron fundamentalmente cuatro las fuentes de mayor importancia en este periodo: El Code Pénal de 1791, el Code Pénal de 1810, el Código Penal español de 1822 y el Código Penal español de 1848-1850.

La Segunda Parte del Code Pénal de 1791, en su Título II, Sección II, contemplaba en los artículos 47 y 48 la regulación del falso testimonio. El primero castigaba con seis años de presidio a quien resultare convicto del crimen de falso testimonio en materia civil. En cambio, el segundo de esos preceptos sancionaba con veinte años de hierros a quien resultare convicto del crimen de falso testimonio, castigo que se reemplazaba por la pena capital si hubiere mediado condena a muerte contra el acusado en cuyo proceso se oyó el falso testimonio ${ }^{99}$.

Por su parte, el Code Pénal de 1810 regulaba el delito de falso testimonio en los crímenes y delitos contra los particulares, específicamente en el capítulo I, sección VII. En efecto, su artículo 361 castigaba al culpable de falso testimonio en materia criminal, ya sea contra el acusado o en su favor, con trabajos forzados temporales. Sin embargo, si el acusado era condenado a una pena mayor que la indicada, se le imponía esa pena al que falsamente hubiere depuesto contra él. En cambio, el artículo 362 sancionaba al culpable de falso testimonio en materia correccional, ya sea en favor o en contra del prevenido, con la pena de reclusión. Mientras que, en virtud de ese mismo precepto, el culpable de falso testimonio en materia de policía, en favor o en contra del prevenido, era castigado con la degradación cívica y prisión de un mes a cinco años. A su turno, el artículo 363 castigaba al culpable de falso testimonio, en materia civil, con la pena de reclusión. Finalmente, el artículo 364 sancionaba al testigo falso en materia correccional o civil que hubiere recibido dinero o admitido cualquiera recompensa o promesa, con trabajos forzados temporales. Y al testigo falso en materia de policía que hubiere recibido dinero o admitido cualquiera recompensa o promesa, se le castigaba con

98 Tomás y Valiente, Francisco, El derecho penal de la monarquía absoluta (siglos XVI, XVII y XVIII) (2 a ed., Madrid, Tecnos, 1992), p. 358.

99 La versión castellana de dichos artículos puede consultarse en GUZMÁn, José Luis, Código Penal Francés de 1791, Traducción y Nota introductoria, en Revista de Derecho Penal y Criminología, 1 (2009), p. 516. 
reclusión. El precepto terminaba disponiendo que, en todo caso, caería en comiso lo que el falso testigo hubiere recibido ${ }^{100}$.

Las bases sentadas por la regulación del falso testimonio contenida en los códigos penales franceses de 1791 y 1810 sirvieron a la tipificación que de ese delito existió en los códigos penales españoles de 1822 y $1848-1850^{101}$.

En el caso del primero, el castigo del falso testimonio se hallaba previsto en el artículo 432, que sancionaba con la pena de infamia al testigo o perito que bajo juramento declarare maliciosa y falsamente en juicio. Pero si su declaración fuere en causa civil, en juicio verbal o en causa criminal sobre delito al que no esté impuesta pena corporal o de infamia por la ley, la pena era de tres a siete años de obras públicas y de cinco a diez si fuere en causa criminal más grave. A esa pena se le aumentaban dos años si, en cualquiera de los dos últimos casos, resultaba haberse sobornado al agente con dones o promesas para efectos de realizar la declaración falsa. No obstante, si la declaración falsa y maliciosa era contra una persona en causa criminal, en que de ser cierto lo declarado se impondría a la persona calumniada otra pena mayor, el perito o testigo falso debía sufrir esa misma pena.

Finalmente, en el Código Penal español de 1848-1850 el delito de falso testimonio se regulaba en los artículos 241 a 247 . El primero de ellos establecía un supuesto de falso testimonio en causa criminal sobre delito grave, que podía reprimirse incluso con la muerte. El artículo 242 consagraba el falso testimonio en causa criminal, pero por delito menos grave, que castigaba con presidio y multa, pena que podía atenuarse si se trataba de una falta. Por su parte, en el artículo 243 se preveía el falso testimonio prestado en favor del reo, que reprimía con presidio y multa, sanción que también podía atenuarse cuando se trataba de una falta. El artículo 244, a su turno, contemplaba el falso testimonio prestado en causa civil, que castigaba con presidio y multa, pena que podía atenuarse si la cuantía del juicio no traspasaba cierto monto. En cambio, el artículo 245 hacía aplicable las penas del falso testimonio a los peritos, mientras que el artículo 246 sancionaba el falso testimonio obtenido mediante cohecho con una pena agravada. En fin, el artículo 247 establecía una figura de falso testimonio privilegiada, aplicable al testigo o perito que no faltare sustancialmente a la verdad, sino que la alterare con reticencias o inexactitudes, que sólo castigaba con pena pecuniaria.

A propósito de la conducta, a pesar de que las normas que regulaban el falso eran considerablemente casuísticas, dicha técnica legislativa no incidía directamente en el comportamiento incriminado. Por el contrario, éste se centraba en la realización de una declaración mendaz ante una autoridad judicial. Aunque en el caso de los códigos penales franceses dicha idea debe ser objeto de un matiz, pues por lo general en ellos se castigaba al convicto o culpable de falso testimonio sin realizar una descripción concreta de la conducta sancionada. Con todo, si se consideran las fuentes indicadas en las etapas anteriores, que sirvieron de referencia

${ }^{100}$ La versión castellana de dichos artículos puede consultarse en PACHECO, Joaquín Francisco, El Código Penal Concordado y Comentado (6 $6^{\mathrm{a}}$ ed., Madrid, Imprenta y Fundición de M. Tello, 1888), II, pp. 331, 338, 341.

${ }^{101}$ Las normas que indicaremos a continuación pueden consultarse en PACHECO, Joaquín Francisco, cit. (n. 100), II. 
a su dictación, es posible afirmar que también en esos cuerpos normativos lo que se castigaba era la emisión de una declaración falsa ante una autoridad judicial.

Tratándose del elemento perjuicio, cabe distinguir entre la regulación francesa y la española antes referidas. En los códigos penales franceses, si bien no existió un reconocimiento explícito del elemento perjuicio, éste sí puede considerarse como parte integrante del sistema de penas de corte talional en ellos previsto, como veremos luego. Además, dicho elemento era reconocido por la doctrina francesa, que entendía que el perjuicio potencial o efectivo era parte del falso testimonio $^{102}$. En el caso de los códigos penales españoles, en cambio, el perjuicio era un factor que claramente se tomaba en cuenta para efectos de establecer la pena aplicable, en que la figura más gravosa, por su mayor prejuicio, era el falso testimonio prestado en causa criminal por delito grave; mientras que la figura menos gravosa, por su menor perjuicio, era el falso testimonio que sólo involucraba reticencias o inexactitudes.

En cuanto al contexto, se advierte en esta etapa la consolidación de una forma específica de regular el falso testimonio que se había esbozado en las Leyes de Toro. De acuerdo con ella, podía cometerse dicho delito tanto en asuntos penales como civiles. Incluso más, en el sistema francés se llegó a diferenciar entre el ámbito penal, administrativo y civil para la comisión del delito. La consolidación de dicha manera de regular el falso testimonio nos plantea la pregunta por su fundamento que, en nuestra opinión, pudo tener su origen en el sistema talional de imposición del castigo, en relación con el cual el falso testimonio cometido en sede penal acarreaba consecuencias más gravosas para el afectado que aquel prestado en sede civil, lo que a su turno debía implicar mayores o menores penas, respectivamente.

Respecto del fuero interno, hay en las fuentes algunas referencias interesantes al mismo, como cuando el Code Pénal de 1810 sancionaba el falso testimonio cometido por una especial motivación: haber recibido dinero o admitido cualquiera recompensa o promesa. Algo similar ocurría con los dos códigos penales españoles ya indicados, que castigaban casos de falso testimonio realizados mediante soborno. Sin embargo, bastante más explícita era la normativa española del Código Penal de 1822 , que castigaba expresamente supuestos de falso testimonio que eran llevados a cabo "maliciosamente". Ahora bien, aunque la regulación francesa no contenía alusiones tan explícitas al elemento intencional en el falso testimonio, la doctrina sí lo reconocía respecto de ese delito, que interpretaba como un comportamiento que suponía la "voluntad" de llevar a cabo la declaración mendaz ${ }^{103}$.

En lo que atañe al juramento, si bien ese rito no se contempló explícitamente en las fuentes relativas a esta etapa, él sí puede considerarse parte del falso testimonio gracias a la regulación del juramento prevista en la normativa procesal. Así, por ejemplo, en el caso del derecho francés se debe tener en cuenta que en 1807 había entrado en vigencia el Code de Procédure Civil, cuyo artículo 262 inciso $2^{\circ}$ establecía el juramento de los testigos como un trámite sustancial, san-

102 Chauveau, Adolphe; Helie, Faustin, Théorie du Code Pénal (4⿳a ed., Paris, Cosse et Marchal, 1862), IV, p. 482.

103 Garraud, René, Traité théorique et pratique du droit pénal français (Paris, Larose, 1901), V, p. 305. 
cionando su omisión con nulidad ${ }^{104}$. Por su parte, en el derecho español, previo a la dictación de la Ley de Enjuiciamiento Civil de 1855, la normativa procesal que contenía disposiciones sobre el juramento de testigos se hallaba tanto en la Nueva Recopilación como en la Novísima Recopilación, que rigieron plenamente hasta su entrada en vigor ${ }^{105}$.

En relación con las penas aplicables, se advierte en esta etapa la influencia del derecho penal de la Ilustración, que implicó una mayor humanización de los castigos que aplicar. Asimismo, el hecho de diferenciar entre diversos contextos de comisión del falso testimonio (penal, administrativo y civil), con sanciones también diferenciadas, expresó una mayor proporcionalidad del castigo establecido para dicho delito.

\section{LA INCLUSIÓN DEL FALSO TESTIMONIO EN EL CÓDIGO Penal Chileno De 1874}

Existen antecedentes en orden a que el falso testimonio, con anterioridad a la dictación del Código Penal chileno de 1874, estuvo regido por la Recopilación de Leyes Indias de $1680^{106}$. En concreto, el Libro VII, título VIII, ley III, contiene referencias a los testigos falsos, cuyo comportamiento delictivo era entendido como una grave ofensa a Dios y a la justicia, y se castigaba de acuerdo con las Leyes del Reino de Castilla ${ }^{107}$. Luego de la independencia de Chile, esta regulación

${ }^{104}$ Griolet, Gaston; Vergé, Charles (dirs.); Bourdeaux, Henry (colab.), Code de Procédure Civile. Annoté d'après la doctrine et la jurisprudence (19ª ed., Paris, Dalloz, 1921), p. 94.

105 Sobre la normativa procesal vigente en España durante la primera mitad del siglo XIX véase Ortells, Manuel, El Code De Procédure Civile de 1806 y la primera codificación procesal civil española: paralelismos, coincidencias, divergencia, en ROMERO, Alejandro (coord.), Estudios de derecho en homenaje a Raúl Tavolari Oliveros (Santiago, LexisNexis, 2007), pp. 3 y ss.

106 Sobre ello PEÑA, Silvia, Las raíces histórico-culturales del derecho penal chileno, en Revista de Estudios Histórico-Jurídicos, 7 (1982), p. 290; desde una perspectiva más general, DE ÁvILA, Alamiro, Esquema del derecho penal indiano (Memoria para optar al grado de licenciado en Ciencias Jurídicas y Sociales, Santiago, Universidad de Chile, 1941), p. 19.

107 Recopilación de Leyes de Indias (1680), 7, 8, 3: Que fean caftigados los teftigos falfos. Somos informados, que en las Indias hay muchos teftigos falfos, que por muy poco interés fe perjuran en los pleytos, y negocios, que fe ofrecen, y con facilidad los hallan quantos fe quieren aprovechar de fus depoficiones. Y porque efte delito es en grave ofenfa de Dios N. Señor, y nueftra, y perjuicio de las partes. Mandamos á las Audiencias, y Iufticias, que con muy particular atencion procuren averiguar los que cometen efte delito, caftigando con todo rigor á los delinquentes, conforme á las leyes de nueftros Reynos de Caftilla, pues tanto importa al fervicio de Dios, y execucion de la jufticia. 
siguió teniendo vigencia en virtud de un senadoconsulto de 7 de junio de 1820 , pero según un orden de prelación, cuyo alcance se discute a nivel doctrinal ${ }^{108-109}$.

Como quedó consignado en la sesión 44 de la Comisión Redactora del Código Penal chileno de 1874, de 12 de junio de 1871, para la tipificación del delito de falso testimonio, y a propuesta del comisionado Fábres, se tuvieron en especial consideración las disposiciones contenidas en el Código Penal español de 1848$1850^{110}$. Cabe tener presente que si bien el referido código constituyó la fuente principal que se tuvo a la vista al momento de tipificar el delito de falso testimonio, en la sesión 44 se introdujeron algunos matices a la regulación hispana. Entre ellos, se acordó asignar un mismo castigo para toda declaración falsa prestada a favor del reo, así como una graduación de penas según la naturaleza del delito por el que ese reo era procesado ${ }^{111}$.

Por otra parte, llama la atención que en la sesión 44 de la Comisión Redactora del Código Penal chileno de 1874 se aludiera al falso testimonio y al perjurio conjuntamente, delitos que fueron analizados y referidos sin efectuar los distingos que habían comenzado a realizarse en las etapas históricas previas. Más aún, existen pasajes en dicha sesión en que las expresiones "falso testimonio" y "perjurio" parecen confundirse ${ }^{112}$, lo que puede valorarse como un retroceso en la regulación autónoma de uno y otro supuesto.

A propósito de la conducta, en la referida sesión 44 se aludió a ésta en términos bastante escuetos, como la "falsa declaración" prestada por el testigo. Esta forma de regular el delito resulta destacable y se aparta del casuismo que caracterizó la etapa inmediatamente anterior. Con ello, no es que existiera una ruptura en la tradición del estatuto del falso testimonio; antes bien, lo que se generó fue una

108 Véase Morales, Marcos, El delito de acusación o denuncia calumniosa (Santiago, Editorial Jurídica Antártica, 1993), p. 40 y NovoA, Eduardo, Curso de derecho penal chileno. Parte general (reimpr. de la $3^{a}$ ed., Santiago, Editorial Jurídica de Chile, 2015), I, pp. 101 y ss. Entre este orden de prelación destacó la regulación del falso testimonio del Libro XII, título VI, ley IV de la Novísima Recopilación, que se remitía a la ley 83 de Toro. Ésta llevaba por epígrafe $A$ los testigos falsos se aé la misma pena que por sus dichos debería darse á aquel contra quien depusieron, y establecía: Quando se probare, que algun testigo depuso falsamente contra alguna persona o personas en alguna causa criminal, en la qual, si no se averiguase su dicho ser falso, aquel ó aquellos contra quien depuso merescian pena de muerte, ó otra pena corporal; que al tal testigo, averiguándose como fué falso, le sea dada la misma pena en su persona y bienes, como se le debiera dar á aquel ó aquellos contra quien depuso, seyendo su dicho verdadero, caso que en aquellos, contra quien depuso, no se execute la tal pena, pues por él no quedó de dársela; la qual mandamos, que se guarde y execute en todos los delitos de qualquier qualidad que sean: y en las otras causas criminales y civiles mandamos, que contra los testigos, que depusieren falsamente, se guarden y executen las leyes de nuestros Reynos que sobre ello disponen.

109 Esto confirma la regla general, según la cual, el derecho de la antigua monarquía siguió estando vigente una vez creada la República de Chile. Véase Guzmán, Alejandro, Andrés Bello codificador: Historia de la fijación y codificación del derecho civil en Chile (Santiago, Ediciones de la Universidad de Chile, 1982), I, pp. 77 y ss.

${ }^{110}$ Véase Rivacoba y Rivacoba, Manuel (dir.), Código Penal de la República de Chile y Actas de las Sesiones de la Comisión Redactora del Código Penal Chileno (Valparaíso, Edeval, 1974), p. 335.

111 Véase Lazo, Santiago, Los códigos chilenos anotados. Código Penal: orígenes, concordancias, jurisprudencia (Santiago, Poblete Cruzat Hnos. Editores, 1915), p. 181.

112 Véase Rivacoba y Rivacoba, Manuel, cit. (n. 110), pp. 335 y s. 
regulación más simple, centrada en el aspecto nuclear de dicho comportamiento que, en todo caso, se interpretó en términos amplios por la primera doctrina y jurisprudencia posterior al Código Penal chileno de $1874^{113}$.

Tratándose del elemento perjuicio, éste no se reguló expresamente en las descripciones típicas del Código Penal chileno de 1874. Sin embargo, como bien apunta Fuensalida, ello no fue impedimento para reconocer la necesidad de que él estuviera presente, en el entendido de que el falso testimonio, como todo delito, implica un daño para otros y para la sociedad ${ }^{114}$.

En cuanto al contexto, se recogió la diferenciación ya prevista en el Código Penal español de 1848-1850 entre falso testimonio prestado en juicio criminal y falso testimonio otorgado en juicio civil. De esta forma, aunque se diferenciaron los ámbitos en los cuales podía cometerse el delito, no se recogió la posibilidad de llevarlo a cabo -también- a propósito de causas correccionales o de policía, como sí hacía la legislación penal francesa ${ }^{115}$.

Respecto del fuero interno, la regulación aprobada por la Comisión Redactora no contuvo referencias explícitas al elemento subjetivo del falso testimonio. No obstante, como el Código Penal chileno de 1874, todavía vigente, parte de la base de que los delitos son dolosos, a menos que ellos se regulen en su forma culposa, es posible concluir que debe existir dolo en quien lleva a cabo la conducta incriminada. Además, puesto que el delito tampoco recogió alusiones explícitas a otros elementos subjetivos distintos del dolo, la doctrina entendió que el falso testimonio podía ejecutarse con cualquier motivación, v. gr. la amistad, el odio o el lucro ${ }^{116}$.

En lo que atañe al juramento, en la sesión 45 de la Comisión Redactora, de 16 de junio de 1871, se indicó que en el falso testimonio no sólo se incluía al que declaraba bajo juramento, sino que también al que deponía sin ese requisito, ya sea por la dignidad que investía, como en el caso de los senadores o jueces; o por la naturaleza de la declaración, como ocurre cuando es un perito el que la efectúa ${ }^{117}$. Esta situación no debe interpretarse como una ruptura respecto de la exigencia del juramento contenida en la tradición histórica del falso testimonio, sino como una regulación de "casos especialísimos" ${ }^{118}$, que escapaban de la regla general.

En relación con las penas aplicables, tratándose del falso testimonio en causa criminal prestado en contra del reo, se resolvió adoptar un sistema talional, según el cual, el delito era castigado con la misma pena impuesta al condenado, salvo que ésta hubiese sido la muerte, en cuyo caso se aplicaba la pena de presidio perpetuo.

113 Así Fernández, Pedro Javier, Código Penal de la República de Chile, esplicado i concordado (2a ed., Santiago, Imprenta, Litografía i Encuadernación Barcelona, 1899), pp. 349 y s. con referencias jurisprudenciales, quien incluye dentro del falso testimonio supuestos en que dicha conducta era llevada a cabo habiendo mediado cohecho, con lo que se acerca a la regulación de dicho delito prevista en algunas de las fuentes medievales.

${ }^{114}$ Véase Fuensalida, Alejandro, Concordancias i comentarios del Código Penal chileno (Lima, Imp. Comercial Calle del Huallaga N. 139, 1883), p. 167.

${ }^{115}$ Fuensalida, Alejandro, cit. (n. 114), p. 165.

116 Fernández, Pedro Javier, cit. (n. 113), p. 349.

117 Véase Vera, Robustiano, Código Penal de la República de Chile, comentado (Santiago, Imprenta de P. Cadot, 1883), p. 388.

${ }^{118}$ Fuensalida, Alejandro, cit. (n. 114), p. 167. 
Esto supuso una notable morigeración del tratamiento penal de dicho delito en relación con el contenido en las fuentes históricas ${ }^{119-120}$, lo que es coherente con el modelo de derecho penal liberal que influyó en la época codificadora.

\section{BiBLIOGRAFÍA}

Alejandre, Juan Antonio, Falsedad testimonial, en Alejandre, Juan Antonio, Falsedad documental y falsedad testimonial. Estudio histórico-jurídico de dos tipos delictivos (Madrid, Dykinson, 2012).

AnTa-Lorenzo, Lauro, El fuero de Sanabria, en Studia Historica. Historia Medieval, 5 (1987). Disponible en: http://revistas.usal.es/index.php/Studia_H_Historia_Medieval/article/view/4304/432. Fecha de consulta: 15.03.2018

Bernì, Joseph, Practica Criminal (Valencia, Simon Faure, 1749).

BlánQuez, Carmen, Desigualdades sociales y praxis jurídica en Apuleyo, en Gerión: Revista de Historia Antigua (1987).

Bühler, G., The Laws of Manu, en Müller, F. Max (ed.), The Sacred Books of the East (Oxford, Clarendon Press, 1886), XXV.

Cantarella, Eva, Los suplicios capitales en Grecia y Roma. Orígenes y funciones de la pena de muerte en la antigüedad clásica (Madrid, Ediciones Akal, 1996).

Carrara, Francesco, Programa de Derecho Criminal. Parte especial (trad. de José Ortega y Jorge Guerrero, Bogotá, Editorial Temis, 1961), V.

Castillo de Bobadilla, Jerónimo, Política para corregidores, y señores de vassallos, en tiempo de paz, y de guerra (Valladolid, Imprenta Real, 1649), II.

Chauveau, Adolphe; Helie, Faustin, Théorie du Code Pénal ( $4^{\mathrm{a}}$ ed., Paris, Cosse et Marchal, 1862), IV.

Cloud, J. D., The primary purpose of the lex Cornelia de sicariis, en Zeitschrift der Savigny-Stiftung für Rechtsgeschichte: Romanische Abteilung, 86/1 (1969).

Cuello Calón, Eugenio, Derecho Penal. Revisado y puesto al día por César Camargo Hernández (14ª ed., Barcelona, Bosch, 1980).

De Avila, Alamiro, Esquema del Derecho Penal indiano (Memoria para optar al grado de licenciado en Ciencias Jurídicas y Sociales, Santiago, Universidad de Chile, 1941).

De la Pradilla, Francisco, Suma de las leyes (Madrid, Imprenta Real, 1644).

De Ureña y Smenjaud, Rafael, El Fuero de Zorita de los Canes según el Códice 217 de la Biblioteca Nacional (Siglo XIII alXIV). Sus relaciones con el Fuero Latino de Cuencay el Romanceado de Alcázar (Madrid, Establecimiento Tipográfico de Fortanet, 1911).

D'Ors, Álvaro, Contribuciones a la historia del "crimen falsi», en Studi in onore di Edoardo Volterra (Milán, Giuffrè, 1969), II.

Fernández, Pedro Javier, Código Penal de la República de Chile, esplicado i concordado (2a ed., Santiago, Imprenta, Litografía i Encuadernación Barcelona, 1899).

Fuensalida, Alejandro, Concordancias i comentarios del Código Penal chileno (Lima, Imp. Comercial Calle del Huallaga N. 139, 1883).

GARCÍA, Ramiro; LARENAS, Melissa, Los albores del derecho penal: la regulación del poder

119 VerA, Robustiano, cit. (n. 117), p. 387.

120 Fuentes que, de acuerdo con Merello, Italo, La ley mariana de fundamentación de sentencias frente a la clemencia judicial en materia penal, en Revista de Estudios Histórico-Jurídicos, 8 (1983), p. 77, a veces consagraron penas tan graves que terminaron por ser desterradas gracias a criterios judiciales más benévolos. 
punitivo en los códigos sumerios, acadios y semitas, en Revista de Derecho Penal y Criminología, 37/102 (2016).

GARRAUD, René, Traité théorique et pratique du droit pénal français (Paris, Larose, 1901), V.

GOMEZ, Juan, Algunos tipos de delitos recogidos en nuestra legislación histórica desde el Fuero Juzgo hasta las Recopilaciones, en Anales de la Universidad de Murcia (1947).

GREEN, Stuart P., Deceit and the classification of crimes: federal rule of evidence 609(A)

(2) and the origins of crimen falsi, en The Journal of Criminal Law \& Criminology, 90/4 (2000).

Griolet, Gastón; Vergé, Charles (dirs.); Bourdeaux, Henry (colab.), Code de Procédure Civile. Annoté d'après la doctrine et la jurisprudence (19ª ed., Paris, Dalloz, 1921).

GuZMÁn, Alejandro, Andrés Bello codificador: Historia de la fijación y codificación del derecho civil en Chile (Santiago, Ediciones de la Universidad de Chile, 1982), I.

GuZMán, José Luis, Código Penal Francés de 1791. Traducción y nota introductoria, en Revista de Derecho Penal y Criminología, 1 (2009).

GuZMÁN, José Luis, La pena y la extinción de la responsabilidad penal (Santiago, Legal Publishing, 2008).

Iglesia, Aquilino, El Derecho en la Cataluña Altomedieval, en Memorias de la Real Academia de Buenas Letras de Barcelona, 24 (1991). Disponible en: http://www.raco.cat/ index.php/MemoriasRABL/article/view/202472. Fecha de consulta: 15.03.2018

IGLESIAS, Luis, El falso testimonio judicial en el derecho hispánico y anglo-sajón en el Medievo. Estudio comparado, en Revista en la España Medieval, 40 (2017).

IGLESIAS, Luis, Estudio comparado de las penas corporales en el derecho hispánico e inglés en la Edad Moderna, en Anuario de Historia del Derecho Español, 86 (2016).

Lara, Federico, Código de Hammurabi (Madrid, Tecnos, 1986).

Lazo, Santiago, Los códigos chilenos anotados. Código Penal: orígenes, concordancias, jurisprudencia (Santiago, Poblete Cruzat Hnos. Editores, 1915).

LÉviTT, Albert, The Origin of the Doctrine of Mens Rea, en Illinois Law Review, 17 (1922-1923).

López-Amo y Marín, Ángel, El Derecho penal español de la Baja Edad Media, en Anuario de Historia del Derecho Español, 26 (1956).

Mayer Lux, Laura; Vera Vega, Jaime, Historia del objeto material del delito de falsedad documental punible, en Revista de Estudios Histórico-Jurídicos, 37 (2015).

Merello, Italo, La ley mariana de fundamentación de sentencias frente a la clemencia judicial en materia penal, en Revista de Estudios Histórico-Jurídicos, 8 (1983).

Mommsen, Theodor, Römisches Strafrecht (Leipzig, Duncker \& Humblot, 1899).

Moncayo, Socorro, El delito de falsedad en el derecho romano, en Revista Letras Juridicas, 2 (2000).

Morales, Juan José; Pedraza, Manuel José, Fueros de Borja y Zaragoza. Edición crítica e indices (Zaragoza, Anubar Ediciones, 1986).

Morales, Marcos, El delito de acusación o denuncia calumniosa (Santiago, Editorial Jurídica Antártica, 1993).

Muñoz y Romero, Tomás, Colección de fueros municipales y cartas pueblas de los reinos de Castilla, León, Corona de Aragón y Navarra (Madrid, Ediciones Atlas, 1978).

NovoA, Eduardo, Curso de derecho penal chileno. Parte general (reimpr. de la $3^{\mathrm{a}}$ ed., Santiago, Editorial Jurídica de Chile, 2015), I.

Orlandis, José, Huellas visigóticas en el derecho de la Alta Edad Media, en Anuario de Historia del Derecho Español, 15 (1944). 
Ortells, Manuel, El Code De Procédure Civile de 1806 y la primera Códificación procesal civil española: paralelismos, coincidencias, divergencia, en RomEro, Alejandro (coord.), Estudios de Derecho en homenaje a Raúl Tavolari Oliveros (Santiago, Lexis Nexis, 2007).

PaCHeCo, Joaquín Francisco, El Código Penal concordado y comentado (6 $6^{\mathrm{a}}$ ed., Madrid, Imprenta y Fundición de M. Tello, 1888), II.

PaCheCo, Joaquín Francisco; González y SerRAno, José, Comentario histórico, crítico y jurídico á las Leyes de Toro (Madrid, Imprenta y Fundición de M. Tello, 1876), II.

PeÑA, Silvia, Las raíces histórico-culturales del derecho penal chileno, en Revista de Estudios Histórico-Jurídicos, 7 (1982).

PINo, Miguel, La pena de confiscación de bienes en el derecho histórico español (Córdoba, Diputación Provincial de Córdoba, 1999).

Rivacoba y Rivacoba, Manuel (dir.), Código Penal de la República de Chile y Actas de las Sesiones de la Comisión Redactora del Código Penal Chileno (Valparaíso, Edeval, 1974).

Rodríguez, Christian, Tratamiento del falso testimonio en las Leyes de Toro, en Revista de Derecho Universidad Católica del Norte (1999).

RodríGuez, Francisco, El mito indio en la perspectiva del mito indoeuropeo, en Gerión: Revista de Historia Antigua (1989).

RodrígueZ, Justiniano, Los Fueros del Reino de León (León, Ediciones Leonesas, 1981), I: Estudio crítico.

Rodríguez, Justiniano, Los Fueros del Reino de León (León, Ediciones Leonesas, 1981), II: Documentos.

Santalucia, Bernardo, Diritto e processo penale nell'antica Roma (2a ed., Milano, Giuffrè, 1998).

TERRADAS, Ignasi, Justicia vindicatoria: de la ofensa e indefensión a la imprecación y el oráculo, la vindicta y el talión, la ordalía y el juramento, la composición y la reconciliación (s. 1., Consejo Superior de Investigaciones Científicas, 2008).

Tomás y Valiente, Francisco, El derecho penal de la monarquía absoluta (siglos XVI, XVII y XVIII) (2a ed., Madrid, Tecnos, 1992).

Torrent, Armando, El Senadoconsulto Messaliano y el "Crimen Falsi", en Anuario de Historia del Derecho Español, 50 (1980).

Valls, Fernando, Los Usatges de Barcelona (Barcelona, Promociones Publicaciones Universitarias, 1984).

Vera, Robustiano, Código Penal de la República de Chile, comentado (Santiago, Imprenta de P. Cadot, 1883).

Volochinsky, Frida, Derecho penal en la antigüedad (Derecho penal hebreo, hindú y griego) (Memoria para optar al grado de licenciado en Ciencias Jurídicas y Sociales, Santiago, Editorial Universitaria, 1961).

WilenMANN, Javier, El concepto de falsedad en el falso testimonio. Una introducción a la dogmática general de los delitos de falsedad, en Revista Chilena de Derecho, 41/1 (2014).

Zambrana, Patricia, Rasgos generales de la evolución histórica de la tipología de las penas corporales, en Revista de Estudios Histórico-Jurídicos, 27 (2005). 